\title{
Phytochemistry and bioactivity of aromatic and medicinal plants from the genus Agastache (Lamiaceae)
}

\author{
Sylwia Zielińska • Adam Matkowski
}

Received: 31 December 2013/Accepted: 25 March 2014/Published online: 3 April 2014

(C) The Author(s) 2014. This article is published with open access at Springerlink.com

\begin{abstract}
Agastache is a small genus of Lamiaceae, comprising 22 species of perennial aromatic medicinal herbs. In this article, we review recent advances in phytochemical, pharmacological, biotechnological and molecular research on Agastache. The phytochemical profile of all Agastache species studied to date is generally similar, consisted of two main metabolic classes-phenylpropanoids and terpenoids. In the relatively variable essential oils, most populations of different Agastache species contain over $50 \%$ of a phenylallyl compound-estragole. Also, other volatile compounds (methyleugenol, pulegone, menthone, isomenthone and spathulenol) were reported in various proportions. Major non-volatile metabolites belong to phenolic compounds, such as caffeic acid derivatives, especially rosmarinic acid as well as several flavones and flavone glycosides like acacetin, tilianin, agastachoside, and a rare dimeric malonyl flavone (agastachin). Two unique lignans-agastenol and agastinol—were also isolated. Terpenoids include triterpenoids of oleanane-type (maslinic acid, oleanolic acid and $\beta$-amyrin), ursane-type (ursolic acid, corosolic acid and $\alpha$-amyrin), and typical plant sterols, as well as abietane-type oxidized diterpenes (e.g., agastaquinone, agastol, and others). The bioactivity of
\end{abstract}

S. Zielińska · A. Matkowski ( $₫)$

Department of Pharmaceutical Biology and Botany,

Medical University of Wroclaw, Borowska 211,

50-556 Wroclaw, Poland

e-mail: pharmaceutical.biology@wp.eu various extracts or individual compounds in vitro and in vivo include antimicrobial, antiviral and antimutagenic activity, cytotoxic activity to cancer cell lines, and anti-nociceptive, anti-inflammatory, antiatherogenic, antioxidant as well as biocidal activity to several foodstuff pests. Biotechnological and molecular studies have focused on in vitro propagation and enhancing the biosynthesis of bioactive metabolites in cell or organ cultures, as well as on the expression of genes involved in phenolic biosynthesis.

Keywords Essential oil - Estragole · Giant hyssop · Phenylpropanoids ·

Tilianin

\section{Introduction}

Throughout the world, hundreds of Lamiaceae (Mint family) species are used as medicinal and aromatic plants. Some of them are among the most popular spices and herbs, like basil, peppermint, sage, and many others. Here, we would like to portray one genus-Agastache Clayt. ex Gronov.- that has similar properties but which is not as commonly recognized. Plants from this genus are known under the vernacular name 'giant hyssop'. Some of these plants are utilized as a source of essential oil, herbal drugs, spice, nectariferous plants in beekeeping, or as ornamentals. Their ornamental use is actually the most common, making giant hyssops one of a few 
examples in the mint family where decorative value appears to overshadow its potential as a medicinal plant. Almost 16 years have passed since the last (and only) systematic review of the Agastache genus was published (Fuentes-Granados et al. 1998). Since then, significant progress in biological investigations has been made. Apart from the morphological, cytogenetical, taxonomic, horticultural and biochemical research that has been previously described, several important biotechnological and molecular studies of Agastache species have appeared in the meantime.

As a result of increasing interest in ethnic and traditional phytotherapeutics, many new studies have been undertaken to examine the pharmacological properties of these herbs, including a few Agastache species. So far, only a few species of the genus Agastache have been fairly represented in the phytochemical and pharmacological literature. Even so, the available data sufficiently support the prospect of increasing use of Agastache spp. and their constituents in herbal therapy.

In the present review, we discuss recent advances in the phytochemistry, bioactivity, molecular biology and biotechnology of Agastache, with an emphasis on the following species: A. foeniculum, A. mexicana, $A$. rugosa, A. scrophulariifolia and A. urticifolia. However, informations about other species are also considered upon their availability in the literature.

For a comprehensive literature overview, we analyzed the published phytochemical and pharmacological data available through several search engines, such as ${ }^{\circledR}$ SciFinder, ISI ${ }^{\circledR}$ Web of Science, ${ }^{\circledR}$ Scopus and ${ }^{\circledR}$ GoogleScholar, using 'Agastache' as the search keyword. We disregarded publications pertaining to agronomy, plant pathology, ecology and other unrelated topics (unless any phytochemical or pharmacological data were provided in them). In a few cases, we found publications using bibliographical data from the reference lists of newer papers to verify the cited information. The major portion of the retrieved citations came from years following the previous review paper of 1998 (Fuentes-Granados et al. 1998).

\section{Botanical description}

The genus Agastache belongs to the Nepetoideae-a subfamily of the Lamiaceae (Cantino et al. 1992). The species of Agastache can be separated into two sections: Brittonastrum and Agastache (Lint and Epling 1945; Sanders 1987).

Plants from Agastache genus are perennial herbs, reaching one meter or more in height. The stems can be simple or branched, erect or slightly creeping, and with an occasionally woody stem base. Their morphology is typical for Lamiaceae, with opposite petiolate leaves, a four-angled stem, numerous trichomes and labiate flowers with pink, purple, white, yellowish or orange corolla. The base chromosome number is 9. Agastache species are native to North America, but one species occurs naturally in East Asia (A. rugosa). Several species are cultivated as ornamentals, with numerous spectacular blooming cultivars. According to the current listing by the taxonomical Internet database lead by the Royal Botanical Gardens at Kew and the Missouri Botanical Garden (www.theplantlist.orgaccessed 31 December 2013), the genus Agastache encompasses the following 29 accepted taxons:

A. aurantiaca (A.Gray) Lint \& Epling

A. breviflora (A.Gray) Epling

A. cana (Hook.) Wooton \& Standl.

A. coccinea (Greene) Lint \& Epling

A. cusickii (Greenm.) A.Heller

A. eplingiana R.W.Sanders

A. foeniculum (Pursh) Kuntze

A. mearnsii Wooton \& Standl.

A. mexicana (Kunth) Lint \& Epling

A. mexicana subsp. mexicana (an infraspecific taxon)

A. micrantha (A.Gray) Wooton \& Standl.

A. nepetoides (L.) Kuntze

A. occidentalis (Piper) A.Heller

A. pallida (Lindl.) Cory

A. pallida var. pallida (an infraspecific taxon)

A. pallidiflora (A.Heller) Rydb.

A. pallidiflora var. greenei (Briq.) R.W.Sanders

A. pallidiflora var. harvardii (A.Gray) R.W. Sanders

A. pallidiflora subsp. neomexicana (Briq.) Lint \& Epling

A. palmeri (B.L.Rob.) Standl.

A. palmeri var. breviflora (Regel) R.W.Sanders

A. parvifolia Eastw.

A. pringlei (Briq.) Lint \& Epling

A. pringlei var. verticillata (Wooton \& Standl.) R. W.Sanders

A. rugosa (Fisch. \& C.A.Mey.) Kuntze 
A. rupestris (Greene) Standl.

A. scrophulariifolia (Willd.) Kuntze

A. urticifolia (Benth.) Kuntze

A. wrightii (Greenm.) Wooton \& Standl.

However, the number of Agastache species recognized has not been constant, and several of them have moved taxonomical positions throughout the years (Lint and Epling 1945; Vogelmann 1985; Sanders 1987; Fuentes-Granados et al. 1998; RBG Kew-the plant list web-based resource, accessed 31 December 2013). In 1945, 22 taxa of Agastache were reported (Lint and Epling 1945), divided into two sections: Brittonastrum and Chiastandra (synonymous with currently recognized section Agastache). Brittonastrum was described as native to the southwestern United States and Mexico, while Chiastandra was described in relation to the northern part of the United States, Canada and East Asia (Lint and Epling 1945). Later, one more species was recognized (A. eplingiana) in an extensive taxonomic study of Brittonastrum (Sanders 1987), two more were separated from those already established (A. pallida and A. mearnsii), and one species was divided into two subspecies, with two or three varieties (A. pallidiflora: $A$. $p$. var. greenei and $A$. $p$. var. havardii).

In 1998, Fuentes-Granados et al. enumerated 22 species of the genus Agastache which had been previously described (Lint and Epling 1945; Vogelmann 1985; Sanders 1987). The placing of a species in either of the two sections is based chiefly on differences in stamen length and arrangement. Although the main criterion of the subgeneric partition seems to be clear-cut, the genetic relationships between the species indicate more complexity (Lint and Epling 1945). Furthermore, morphological similarities between species of the same section do not necessarily indicate close genetic affinity (Table 1). Analysis of isoenzyme profiles and multivariate morphological classification have demonstrated that both morphological features and genetic distances between species of both sections are not consistently greater than within each section (Vogelmann 1985; Sanders 1987). A. rugosa appeared to be more similar to the eastern North-American populations than to the western North-American populations of sect. Agastache (Vogelmann and Gastony 1987). Moreover, there is less intraspecific variation in the Agastache section than in Brittonastrum (Lint and Epling 1945).
The morphology of leaf laminas as well as stemtypes and inflorescence were described in detail in Fuentes-Granados et al.'s review (1998) and some earlier papers (Lint and Epling 1945; Vogelmann 1985; Sanders 1987). Generally, the leaves of plants from the Agastache section are longer (up to $15 \mathrm{~cm}$ ) than those of Brittonastrum $(2-6 \mathrm{~cm})$. Plants from the Agastache section have ovate laminas with a crenateserrate leaf margin, whereas those of Brittonastrum are more diverse. In the latter section, the basic leaf form is cordate-triangular, but juvenile laminas are ovate-to-cordate and mature-cordate, ovate, narrowly ovate or oblong-linear. Leaf margins are usually crenate, sometimes entire (Sanders 1987). The stems of plants from the Agastache section are simple or else branched with dense spicate inflorescences formed at terminal apices (Lint and Epling 1945). The inflorescence of Brittonastrum plants is basically an elongate thyrse. However, in various species and environmental conditions, it can be either continuous and spike-like-to-brush-like or else discontinuous and moniliform-to-loosely ramified, with a lower cymose clusters often remote from the upper (Sanders 1987). However, the latter feature can also appear in species from the Agastache section (Fuentes-Granados et al. 1998).

The morphology of Agastache and Brittonastrum flowers is also different (Sanders 1987). A typical Agastache section corolla is asymmetrically and narrowly funnel-formed, and slightly two-lipped. Two adaxial lobes are fused for about two-thirds of their length into a shallowly concave upper lip. Two lateral lobes are much exceeded by the upper lip. Four stamens are exserted from the tube and included under the greatly exceeding upper corolla lip. The dorsal pair of stamens is longer (didynamous). In Brittonastrum, the corolla mouth is oblique with small lobes (less than one-quarter of the entire corolla length). The lateral lobes are fused more to the upper lip than to the median lobe. Stamens are included under or shortly exerted beyond the upper corolla lip.

From the several species considered here ( $A$. rugosa, A. foeniculum, A. urticifolia, A. scrophulariifolia, $A$. mexicana and $A$. nepetoides), only $A$. mexicana is a member of the Brittonastrum section. The morphological and chemical investigations of $A$. mexicana suggested a new, white flowering taxon named A. mexicana subsp. xolocotziana Bye, Linares \& Ramamoorthy (Bye et al. 1987). Hence, $A$. 
Table 1 Comparison of selected botanical traits of six Agastache species

\begin{tabular}{|c|c|c|c|c|c|}
\hline Species & Common name & Distribution & Corolla color & Height $[\mathrm{cm}]$ & References \\
\hline $\begin{array}{l}\text { A. foeniculum* } \\
\text { (Pursh) O. Kuntze } \\
\text { Britton }\end{array}$ & $\begin{array}{l}\text { Blue (giant) hyssop, } \\
\text { anise hyssop }\end{array}$ & $\begin{array}{l}\text { Northern Great Plains } * * * \\
\text { Western Great Lakes*** }\end{array}$ & Blue & $\begin{array}{l}\text { Less than } \\
100\end{array}$ & $\begin{array}{l}\text { Lint and Epling } \\
\text { (1945), Ayers and } \\
\text { Widrlechner } \\
\text { (1994) }\end{array}$ \\
\hline $\begin{array}{l}\text { A. nepetoides* (L.) } \\
\text { O. Kuntze }\end{array}$ & $\begin{array}{l}\text { Yellow/catnip } \\
\quad \text { (giant) hyssop }\end{array}$ & $\begin{array}{l}\text { Southern New England } \\
\text { Southern Great Lakes*** } \\
\text { Ohio River Basin } \\
\text { Ozarks }\end{array}$ & Greenish yellow & 100 or more & $\begin{array}{l}\text { Lint and Epling } \\
\text { (1945), Ayers and } \\
\text { Widrlechner } \\
\text { (1994) }\end{array}$ \\
\hline $\begin{array}{l}\text { A. rugosa* (Fisch. \& } \\
\text { C.A. Mey.) O. } \\
\text { Kuntze }\end{array}$ & $\begin{array}{l}\text { Wrinkled (giant) } \\
\text { hyssop, Korean } \\
\text { mint }\end{array}$ & $\begin{array}{l}\text { Korea, East China } \\
\text { Japan, Manchuria and Russian } \\
\text { Far East }\end{array}$ & Purplish blue & 100 or more & $\begin{array}{l}\text { Lint and Epling } \\
\text { (1945), Ayers and } \\
\text { Widrlechner } \\
\text { (1994) }\end{array}$ \\
\hline $\begin{array}{l}\text { A. scrophulariifolia* } \\
\text { (Wilde) O. Kuntze }\end{array}$ & $\begin{array}{l}\text { Purple (giant) } \\
\text { hyssop, figwort } \\
\text { (giant) hyssop, } \\
\text { prairie hyssop }\end{array}$ & $\begin{array}{l}\text { Southern New England } \\
\text { Southern to Western South } \\
\text { Carolina } \\
\text { Western to Northern Missouri } \\
\text { Southern Minnesota }\end{array}$ & $\begin{array}{l}\text { Pale pink to } \\
\text { purple }\end{array}$ & Up to 210 & $\begin{array}{l}\text { Lint and Epling } \\
\text { (1945), Ayers and } \\
\text { Widrlechner } \\
\text { (1994), Corrigan } \\
\text { (2002) }\end{array}$ \\
\hline $\begin{array}{l}\text { A. urticifolia* } \\
\text { (Benth.) }\end{array}$ & $\begin{array}{l}\text { Nettle-leaf (giant) } \\
\text { hyssop, horse } \\
\text { nettle }\end{array}$ & $\begin{array}{l}\text { Sierra Nevada } \\
\text { Eastern Cascades } \\
\text { Great Basin } \\
\text { Northern Rockies*** }\end{array}$ & $\begin{array}{l}\text { Bright purple } \\
\text { and pink }\end{array}$ & $\begin{array}{l}\text { 100-200 or } \\
\text { more }\end{array}$ & $\begin{array}{l}\text { Lint and Epling } \\
\text { (1945), Ayers and } \\
\text { Widrlechner } \\
\text { (1994), Manning } \\
\text { and Padgett } \\
\text { (1991) }\end{array}$ \\
\hline $\begin{array}{l}\text { A. mexicana** } \\
\text { (Kunth) Lint \& } \\
\text { Epling }\end{array}$ & $\begin{array}{l}\text { Mexican (giant) } \\
\text { hyssop, toronjil } \\
\text { morado/rojo/ } \\
\text { colorado, nahuatl, } \\
\text { tepehua }\end{array}$ & Cuijingo and Ozumba, Mexico & $\begin{array}{l}\text { Purplish red to } \\
\text { red }\end{array}$ & $50-150$ & $\begin{array}{l}\text { Sanders (1987), } \\
\text { Hersch-Martinez } \\
\text { (1997), Ibarra- } \\
\text { Alvarado et al. } \\
\text { (2010) }\end{array}$ \\
\hline
\end{tabular}

* Sect. Agastache

** Sect. Brittonastrum

*** USA/Canada

mexicana has been placed into the nomotypical subspecies A. mexicana subsp. mexicana. See also the 'phytochemistry' section below for details on the chemical differences between these two subspecies.

Synonyms of the five species covered by the present review (theplantlist.org)

sect. Agastache

Agastache foeniculum (Pursh) O. Kuntze Britton (Agastache anethiodora (Nutt.) Britton \& A. Br., Agastache foeniculum f. bernardii B. Boivin, Agastache foeniculum f. candicans B. Boivin, Hyptis marathrosma (Spreng.) Benth., Hyssopus anethiodorus Nutt., Hyssopus anisatus Nutt., Hyssopus discolor Desf., Hyssopus foeniculum (Pursh) Spreng., Lophanthus anisatus (Nutt.) Benth., Lophanthus foeniculum
(Pursh) E.Mey., Perilla marathrosma Spreng., Stachys foeniculum Pursh, Vleckia albescens Raf., Vleckia anethiodora (Nutt.) Greene, Vleckia anisata (Nutt.) Raf., Vleckia bracteata Raf., Vleckia bracteosa Raf., Vleckia discolor Raf., Vleckia foeniculum (Pursh) MacMill., Vleckia incarnate Raf.)

Agastache rugosa (Fisch. \& C.A. Mey.) O. Kuntze (Agastache formosana (Hayata) Hayata ex Makino \& Nemoto, Agastache rugosa f. alba Y.N. Lee, Cedronella japonica Hassk., Elsholtzia monostachys H.Lév. \& Vaniot, Lophanthus argyi H.Lév., Lophanthus formosanus Hayata, Lophanthus rugosus Fisch. \& C.A.Mey.)

Agastache scrophulariifolia (Wilde) O. Kuntze (Agastache scrophulariifolia var. mollis (Fernald) A. 
Heller, Hyssopus catariifolius Benth., Hyssopus scrophulariifolius Willd., Lophanthus scrophulariifolius (Willd.) Benth., Lophanthus scrophulariifolius var. mollis Fernald, Vleckia cordifolia Raf., Vleckia scrophularifolia (Willd.) Raf.)

Agastache urticifolia (Benth.) Kuntze (Agastache glaucifolia A.Heller, Agastache urticifolia var. glaucifolia (A.Heller) Cronquist, Lophanthus urticifolius Benth., Vleckia urticifolia (Benth.) Raf.).

\section{sect. Brittonastrum}

Agastache mexicana (Kunth) Lint \& Epling (Brittonastrum mexicanum (Kunth) Briq., Cedronella mexicana (Kunth) Benth., Dracocephalum mexicanum Kunth, Dekinia coccinea Martens \& Galeotti, Gardoquia betonicoides Lindley).

\section{Phytochemistry}

Agastache species-typically for Lamiaceae-are abundant in phenylpropanoid and terpenoid specialized metabolites. The first group includes flavonoids, free phenolic acids and depsides as well as lignans. The second major group-terpenoids are contained in volatile fractions as well as in various organs as nonvolatiles. Most of the published studies focus on essential oil analysis. There are also numerous papers reporting the isolation and elucidation of the structure of various phytochemicals.

Overview of extraction, analysis and purification methods

Determination of volatile constituents:

- Essential oil hydrodistillation using Clevenger apparatus or pharmacopoeia distillation apparatus (Charles et al. 1991; Mazza and Kiehn 1992; Svoboda et al. 1995; Dung et al. 1996; Tirillini et al. 1997; Dapkevicius et al. 1998; Kim et al. 2001a; Maruyama et al. 2002; Shin and Kang 2003; Omidbaigi and Sefidkon 2003, 2004; Estrada-Reyes et al. 2004; Mallavarapu et al. 2004; Shin and Pyun 2004; Bruni et al. 2007; Omidbaigi et al. 2008; Tian et al. 2009; Ebadollahi et al. 2010, 2011; Omidbaigi and Mahmoodi 2010; Skakovskii et al. 2010; Gong et al. 2012a, b; Li et al. 2013);
- Essential oil distillation-extraction (Wang 2010);

- Extraction with organic solvents: hexane, hexane-EtOAc mixtures, EtOAc, EtOAc-MeOH mixtures, $\mathrm{MeOH}$, dichloromethane (Kim et al. 2001b; Shin et al. 2001; Estrada-Reyes et al. 2004);

- Extraction with diethyl ether and boiling methanol followed by cold storage $\left(-20^{\circ} \mathrm{C}\right)$ and steam distillation (Weyerstahl et al. 1992);

- Headspace (Mazza and Kiehn 1992; Wilson et al. 1992; Zielinska et al. 2011);

- Glass microneedles used for the determination of secretory trichomes constituents (Tirillini et al. 1997).

Determination of non-volatile compounds

Plant material, such as aerial parts, roots and cell, tissue and organ cultures were extracted with various organic solvents of different polarities applied either independently or sequentially: n-hexane, petrol, petroleum ether, dichloromethane, chloroform, ethyl acetate, n-butanol, acetone, ethanol, methanol (two latter solvents also mixed with water) or water alone. Various extraction techniques were applied: maceration at ambient or elevated temperature, reflux extraction, infusions and decoctions in hot water. The extracts were usually dried under reduced pressure or by lyophilization (Itokawa et al. 1981; Ganeva et al. 1994; Lee et al. 1995, 2002, 2007, 2008; Kim et al. 1999; Molina-Hernandez et al. 2000; Suvitayavat et al. 2004; Vera-Montenegro et al. 2008; $\mathrm{Xu}$ et al. 2008; Hernandez-Abreu et al. 2009, 2011, 2013; Gonzalez-Trujano et al. 2012).

A few additional methods were used in a comparative study of the extraction of several herbs, including A. foeniculum (Dapkevicius et al. 1998):

- Deodorized acetone extract obtained by reextracting all the dried solid retentate remaining after hydrodistillation with acetone under continuous shaking;

- Deodorized water extracts concentrated from the liquid retentate remaining after hydrodistillation;

- Supercritical $\mathrm{CO}_{2}$ extracts;

- Acetone extracts;

- Methanol-water extracts obtained by re-extracting the plant material remaining after the acetone extraction. 
The headspace volatile organic compounds and the essential oil were usually analyzed using the gas chromatography mass spectrometry technique (GCMS). For quantitative analysis, gas chromatography was used with a flame ionization detector (GC-FID) (Charles et al. 1991; Mazza and Kiehn 1992; Weyerstahl et al. 1992; Wilson et al. 1992; Svoboda et al. 1995; Dung et al. 1996; Tirillini et al. 1997; Kim et al. 2001; Estrada-Reyes et al. 2004; Mallavarapu et al. 2004; Bruni et al. 2007; Mo et al. 2009; Tian et al. 2009; Ebadollahi et al. 2010; Omidbaigi and Mahmoodi 2010; Wang 2010; Mo and Ma 2011; Gong et al. 2012a; Li et al. 2013; Lim et al. 2013). Non-volatile analysis was usually made with reversed phase HPLC using C18 silica columns eluted with acetonitrile/water or methanol/water mixtures, with photometric detection. Individual isolated compounds were identified by routine spectroscopic methods such as ${ }^{1} \mathrm{H}$ and ${ }^{13} \mathrm{C}$ NMR, UV/VIS, infrared, and mass spectrometry (RA —Kim et al. 1999; acacetin, tilianin, agastachoside, linarin-Zakharova et al. 1980; thymol, myrcene, limonene, $\beta$-caryophyllene, pulegone, menthone, isomenthone, camphor, linalyl acetate, linalool, $\beta$ phellandrene-Skakovskii et al. 2010; acacetin, tilianin, isoagastachoside, agastachin-Itokawa et al. 1981; Hernandez-Abreu et al. 2009; agastinol, agastenol-Lee et al. 2002, agastaquinone-Lee et al. 1995).

The compounds were mostly purified using column chromatography on silica gel eluted with various solvents, sometimes preceded by liquid-liquid extraction:

- Chloroform-methanol mixture, methanol-water mixture, chloroform-methanol mixture, methanol (RA-Kim et al. 1999; tilianin-Hong et al. 2001; agastinol, agastenol-Lee et al. 2002);

- Petroleum ether-acetone mixture (estragole, methyleugenol—Li et al. 2013);

- Ethyl acetate/n-hexane gradient n-hexane/chloroform/methanol (for the elution of fractions) (agastaquinone-Lee et al. 1995);

- Hexane-ethyl acetate (l-pulegone-Maruyama et al. 2002, Estrada-Reyes et al. 2004; estragole, triterpenoids, flavonoids-Estrada-Reyes et al. 2004).

Further purification steps included column chromatography on different stationary phases, like C18 silica gel or Sephadex LH-20, sometimes finalized by preparative reversed-phase HPLC (on C18 columns).
In bioactivity or environmental-screening studies, simple colorimetric assays were used for the determination of the total content of certain metabolite classes, like polyphenols (with a Folin-Ciocalteu reagent), hydroxycinnamic acids (the European Pharmacopoeia method) and flavonoids (with aluminum chloride) (Suchorska-Tropiło and Pióro-Jabrucka 2004; Ibarra-Alvarado et al. 2010).

Essential oil composition

Typically for Nepetoideae, the volatiles produced by Agastache plants are synthesized and stored in glandular trichomes localized in crypts on the leaf surface. These specialized morphological structures appear during leaf development and are fully differentiated in mature organs. Apart from the glandular trichomes, the leaf lamina of different Agastache species is more or less covered with non-secreting hair. In some species, like A. foeniculum, the hair cover is particularly dense (Svoboda et al. 1995). Depending on the species and plant organ, the oil yield can reach above $2 \%(\mathrm{v} / \mathrm{w})$ (the specific values are given in Table 2) (Charles et al. 1991; Svoboda et al. 1995; Omidbaigi and Sefidkon 2004; Omidbaigi et al. 2008; Omidbaigi and Mahmoodi 2010). In most of the studies the essential oil was obtained by the hydro-distillation of aerial parts, either all together (herb) or separated into leaves and inflorescences (Charles et al. 1991, Svoboda et al. 1995; Dung et al. 1996, Omidbaigi and Sefidkon 2003, 2004; Mallavarapu et al. 2004; Omidbaigi et al. 2008; Ebadollahi et al. 2010; Omidbaigi and Mahmoodi 2010; Gong et al. 2012a, 2012b; Li et al. 2013).

The content of essential oil in the herb of different Agastache species depends upon the time of harvest as well as on the environmental conditions or methods of cultivation (Omidbaigi and Mahmoodi 2010; Omidbaigi et al. 2008; Omidbaigi and Sefidkon 2004; Suchorska-Tropiło and Pióro-Jabrucka 2004; Svoboda et al. 1995). For example, the highest oil yield from $A$. mexicana, and A. rugosa was at the beginning, whereas from $A$. foeniculum in the middle of blooming period (Suchorska-Tropiło and PióroJabrucka 2004). A. rugosa and A. scrophulariifolia grow well and give a higher yield of essential oil in cooler summer temperatures. Conversely, A. foeniculum and A. urticifolia prefer warmer conditions, otherwise they do not bloom and produce only 
Table 2 Yield of essential oil (from dried herbal material) obtained from different Agastache species

\begin{tabular}{lll}
\hline Species & $\begin{array}{l}\text { Oil yield } \\
(\% \text { v/w }) \text { d.w. }\end{array}$ & References \\
\hline A. foeniculum & $0.07-3.00$ & Charles et al. (1991) \\
$0.02-0.74$ & Svoboda et al. (1995) \\
1.87 & Omidbaigi and Sefidkon (2003) \\
$1.5-1.8$ & Mallavarapu et al. (2004) \\
2.0 & Omidbaigi and Sefidkon (2004) \\
$0.5-0.8$ & Suchorska-Tropilo and Pióro-Jabrucka (2004) \\
$2.1-2.88$ & Omidbaigi et al. (2008) \\
2.3 & Omidbaigi and Mahmoodi (20100 \\
1.45 & Svoboda et al. (1995) \\
A. mexicana & $0.4-0.6$ & Suchorska-Tropilo and Pióro-Jabrucka (2004) \\
$1.53-2.73$ & Charles et al. (1991) \\
A. rugosa & $0.92-2.28$ & Svoboda et al. (1995) \\
& $0.5-0.8$ & Dung et al. (1996) \\
0.19 & Maruyama et al. (2002) \\
A. urticifolia & $0.3-1.0$ & Suchorska-Tropilo and Pióro-Jabrucka (2004) \\
\hline & 0.37 & Wang (2010) \\
$0.29-0.57$ & Gong et al. (2012a) \\
0.32 & Li et al. (2013) \\
0.99 & Svoboda et al. (1995) \\
0.89 & Svoboda et al. (1995) \\
& &
\end{tabular}

negligible amounts of oil (Svoboda et al. 1995; Rudik 2013).

Moreover, plants from five Agastache species-A. foeniculum, A. mexicana, A. rugosa, A. scrophulariifolia, and A. urticifolia (Svoboda et al. 1995)produced significantly more essential oil during the flowering phase than during vegetative growth. The yield decreased again before senescence time.

The sowing time is also an important factor influencing both the quantity and quality of essential oil from A. foeniculum (Omidbaigi and Sefidkon 2004). Early sowing (March) was advantageous over later months (May, July) resulting in higher yields (2\%) and estragole content $(92 \%)$. The same research group determined the positive effect of nitrogen fertilization, which could improve the essential oil yield by up to $2.88 \%$ (at $100 \mathrm{~kg} \mathrm{~N} /$ ha). The moderate irrigation of fields in the vicinity of Tehran (Iran) was also beneficial (the highest yield was ca. $2.3 \%$ ), but this treatment does not need to be equally useful for areas with less arid conditions during summer (Omidbaigi et al. 2008; Omidbaigi and Mahmoodi 2010).
Although the composition of volatiles from the Agastache species is relatively variable, some of the constituents are usually predominating or else comprise a substantial fraction (Figs. 1, 2, 3). However, there are some discrepancies in the results of particular reports on several species as regards the stability of composition and the influence of environmental or hereditary factors.

Two main classes of volatile compounds arephenylpropanoids and terpenoids. The latter comprise more abundant monoterpenes (hydrocarbons and oxidized) and sesquiterpenes, usually present only in small amounts.

Estragole confers the most typically-described anise-like aroma to the plants and essential oils of A. rugosa, A. foeniculum and A. mexicana (FuentesGranados et al. 1998). Estragole (syn.: methyl chavicol, p-allylanisol, 4-metoxyallylbenzene) is usually the most abundant constituent (18.6\% to over $98 \%$ ) in A. rugosa and A. foeniculum aerial parts (Fujita and Fujita 1973; Charles et al. 1991, 1992; Mazza and Kiehn 1992; Weyerstahl et al. 1992; Wilson et al. 1992; Svoboda et al. 1995; Dung et al. 
Fig. 1 Structures of typical monoterpenoids from Agastache
Fig. 2 Sesquiterpenoids from Agastache

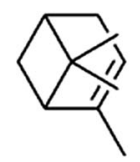

$\alpha$-Pinene

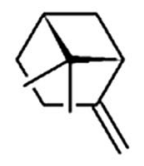

$\beta$-Pinene

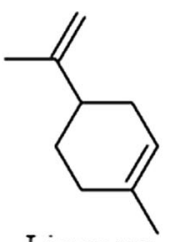

Limonene<smiles>CC1=CCC(C(C)C)=CC1</smiles>

$\alpha$-Terpinene<smiles>CC1=CCC(O)(C(C)C)CC1</smiles>

$\alpha$-Terpineol

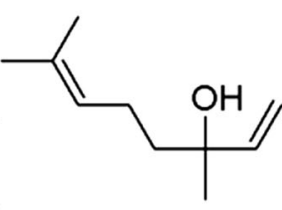

Linalool

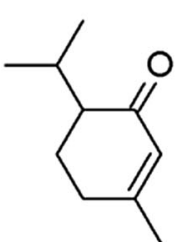

Piperitone

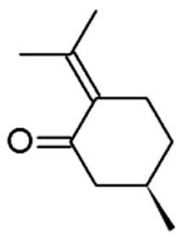

Pulegone

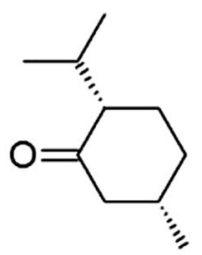

(-)Isomenthone

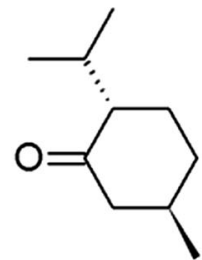

Menthone

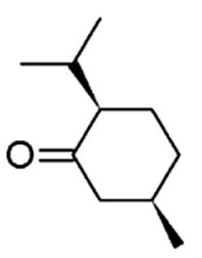

(+)Isomenthone

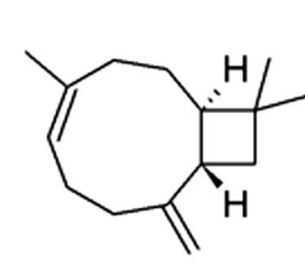

$\beta$-Caryophyllene

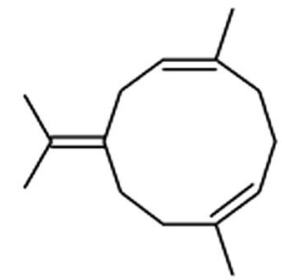

Germacrene B

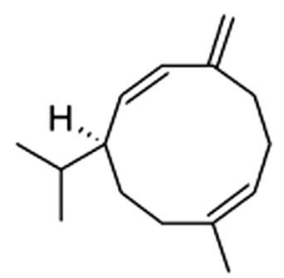

Germacrene D

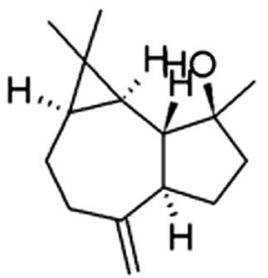

Spathulenol<smiles>CC1=C[C@H]2C(C(C)C)CC=C(C)[C@H]2CC1</smiles>

$\beta$-Muurolene<smiles>C=C1CC[C@H](C(C)C)[C@H]2C=C(C)CC[C@H]12</smiles>

$\gamma$-Muurolene<smiles>CC1=C[C@H]2[C@@H](C(C)C)CCC(C)(O)[C@@H]2CC1</smiles>

$\tau$-Muurolol<smiles>CC1=C[C@H]2[C@@H](C(C)C)CCC(C)(O)[C@]2(O)CC1</smiles>

ô-Cadinol
Fig. 3 Structures of volatile phenolic compounds from Agastache

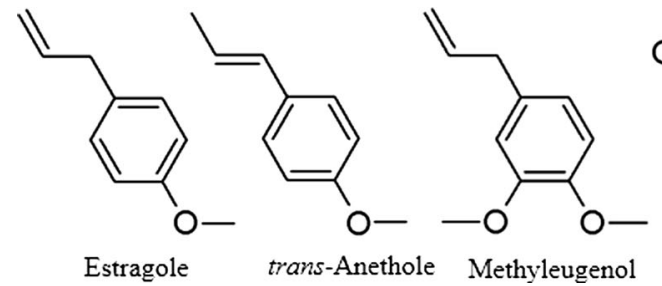

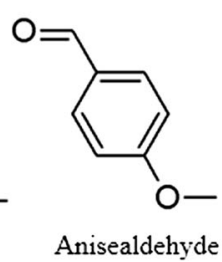

Anisealdehyde Methoxycinnamaldehyde
1996; Tirillini et al. 1997; Omidbaigi and Sefidkon 2004; Skakovskii et al. 2010; Wang 2010; Zielinska et al. 2011; Lim et al. 2013). In essential oils from other Agastache species (A. mexicana, A. mexicana subsp. xolocotziana and $A$. scrophulariifolia) estragole was reported in various proportions (from absent to over 86 \%) (Svoboda et al. 1995; Estrada-Reyes et al. 2004; Suchorska-Tropilo and Pióro-Jabrucka 2004). Other phenylpropene volatiles are also present in varying amounts in Agastache. There are populations and individuals that are distinct in their essential oil compositions from the most commonly described. For example, the closest biosynthetic relative of estragole-methyleugenol—was a main compound 
(over $85 \%$ ) in some specimens from Japan (Fujita and Fujita 1973), China (Li et al. 2013), and in Korean accessions (Chae et al. 2005). The latter authors suggest the existence of five chemotypes, based on the analysis of specimens of various geographical origins, cultivated in similar conditions: 1-the typical estragole-containing one (distributed throughout the species range), and four others (limited in their occurrence to one province)—with major constituents of headspace volatiles being: 2menthone, 3-menthone and pulegone, 4-methyleugenol, and 5-methyleugenol and limonene. In $A$. rugosa, essential oil samples from Western China, Gong et al. (2012a, b) reported large amounts (48.8 and $19.2 \%)$ of $p$-menthan-3-one ((-)isomenthone), estragole (20.8 and $29.5 \%$ ) and monoterpenes $(8.8 \%)$. Estragole was not detected in the essential oil of A. mexicana cultivars or A. scrophulariifolia, while the samples were rich in pulegone, at 75.3 and $45.2 \%$ respectively (Svoboda et al. 1995; EstradaReyes et al. 2004). A. foeniculum can also contain up to $19.6 \%(E)$-anethole, as the second most abundant compound after estragole $(59.5 \%)$ in directly-sampled (with microneedle) secretory trichomes (Tirillini et al. 1992). However, anethole and other phenylallyls were usually detected in Agastache sp. only as minor compounds (Fuentes-Granados et al. 1998; Zielińska et al. 2011). In comparative analyses of 15 A. foeniculum populations, those of them with a low estragole content were high in sesquiterpenoid spathulenol (10.5-49.5\%) accompanied by various amounts of bornyl acetate (Charles et al. 1991). Moreover, these accessions also had a markedly lower essential oil content $(0.07-0.36 \%)$ than estragole-rich ones (0.80-2.45\%). The significance of such relationships has not yet been clarified, but it could relate to some environmental (rather than hereditary) factors. Interestingly, sesquiterpenes $(\delta-$ cadinol, $\beta$-caryophyllene and spathulenol) were also predominant in $A$. nepetoides, analyzed during the same study and likewise poor in essential oil $(0.18 \%)$. One of the volatile monoterpenoids that is produced in a higher proportion by different species of Agastache is pulegone. It was reported in large amounts in the essential oil of A. rugosa (13.4$50.8 \%$ (Svoboda et al. 1995; Maruyama et al. 2002; Mo et al. 2009; Mo and Ma 2011), A. foeniculum (22.6 \%), A. scrophulariifolia (45.2\%) (Svoboda et al. 1995) and A. mexicana subsp. xolocotziana
(80\%), but not in A. mexicana subsp. mexicana (Estrada-Reyes et al. 2004).

Major volatiles are usually accompanied by less abundant monoterpenes (e.g., $d$-limonene, $\alpha$-pinene, $\beta$ pinene, $\gamma$-terpinene, $\alpha$-terpineol, linalool, thymol, menthofuran) and sesquiterpenes (e.g., $\beta$-caryophyllene, carvacrol, germacrene B, germacrene D) (Polak and Hixon 1945; Fujita and Fujita 1973; Charles et al. 1991; Mazza and Kiehn 1992; Weyerstahl et al. 1992; Wilson et al. 1992; Tirillini et al. 1997; Maruyama et al. 2002; Omidbaigi and Sefidkon 2003; Mallavarapu et al. 2004; Zielinska et al. 2011; Li et al. 2013). Recently, several sesquiterpenoids (elixene, $\gamma$-muurolene, viridiflorol, $\tau$-muurolol), previously unknown from this genus, have been reported in the essential oil of $A$. rugosa aerial parts obtained by hydrodistillation (Li et al. 2013). In a volatile fraction obtained by simultaneous distillation-extraction, $\beta$-muurolene was present in a considerable amount, in $1.42 \%$ of the total volatile fraction (Wang 2010). The analysis of essential oils from the leaves and flowers of $A$. foeniculum, $A$. rugosa and putative hybrids between $A$. rugosa and $A$. foeniculum was reported by Charles et al. (1991) who examined 19 different accessions (11 of $A$. foeniculum, four of $A$. rugosa and four of $A$. rugosa $\mathrm{x}$ A. foeniculum putative hybrids). In seven samples from $A$. foenicu$l u m$, neither menthone nor isomenthone were detected. The other four contained a low percentage of isomenthone $(0.14,0.17,0.88$ and $1.12 \%)$. By contrast, isomenthone $(0.31 \%$ to $3.33 \%)$ was present in $A$. rugosa and putative hybrids between $A$. rugosa and $A$. foeniculum. These hybrids were identified by the leaf and inflorescence morphology (Charles et al. 1991). However, in another study on four populations of $A$. foeniculum, the content of isomenthone was more diverse, ranging from 0 to $37.1 \%$ (Svoboda et al. 1995).

Infection by the cucumber mosaic virus (CMV) caused alteration in the composition of $A$. foeniculum essential oil (Bruni et al. 2007). The most significant differences were observed in the content of estragole, isomenthone, pulegone and limonene. The concentrations of limonene and isomenthone increased, respectively, from 2.8 to $12.0 \%$, and from 27 to $43.9 \%$, whereas estragole and pulegone decreased from 16.2 to $3.2 \%$, and from 31.2 to $18.7 \%$. A significant quantitative decline of the oil yield (3.5 $\mathrm{ml} / \mathrm{kg}$ - healthy plants, $0.4 \mathrm{ml} / \mathrm{kg}$-infected plants) was also observed (Bruni et al. 2007). 
Phenolic compounds

Caffeic acid derivatives - especially rosmarinic acid and several glycosylated flavonoids are the most abundant non-volatile phenolic metabolites in different Agastache species (Fig. 4). The content of both flavonoids and phenolic acids depends on the plant organ and the ontogenetic phase, and also on external factors such as biotic and abiotic stress and environmental conditions.

\section{Flavonoids}

One of the typical flavones reported in Agastache is an acacetin (5,7-dihydroxy-4'-methoxyflavone) glycoside-tilianin (acacetin-7-O- $\beta$-D-glucopyranoside) present in the aerial parts and roots of $A$. rugosa and A. mexicana (Itokawa et al. 1981; Zou and Cong 1991; Tuan et al. 2012; Hernandez-Abreu et al. 2013). This compound appears to be more representative for $A$. mexicana than for A. rugosa. The content of tilianin in A. mexicana aerial parts measured in various methanol extracts was over $8 \mathrm{mg} / \mathrm{g}$ of dried herb (Hernandez-Abreu et al. 2011). A. rugosa contains much lower amounts of tilianin, reaching $6.33 \mu \mathrm{g} / \mathrm{g}$ d.w. in flowers and even less in other organs $(2.18 \mu \mathrm{g} / \mathrm{g}$ in leaves, $0.49 \mu \mathrm{g} / \mathrm{g}$ in stems, and $0.14 \mu \mathrm{g} / \mathrm{g}$ in roots) (Tuan et al. 2012). However, Hong et al. (2001) were able to isolate almost $50 \mathrm{~g}$ of pure tilianin from $30 \mathrm{~kg}$ of herb (yield of about<smiles>O=C(/C=C/c1ccc(O)c(O)c1)OC(Cc1ccc(O)c(O)c1)C(=O)O</smiles><smiles>O=c1cc(-c2ccc(O)cc2)oc2cc(O)cc(O)c12</smiles><smiles>COc1ccc(-c2cc(=O)c3c(O)cc(O)cc3o2)cc1</smiles><smiles>COc1cc(OC2CO[C@H](c3ccc(/C=C4\CO[C@H](c5ccc(O)c(OC)c5)[C@@H]4COC(=O)c4ccc(O)cc4)c(OC)c3)C2COC(=O)c2ccc(O)cc2)ccc1O</smiles><smiles>COc1ccc([C@@H]2CC(=O)c3c(O)cc(O)cc3O2)cc1O</smiles><smiles>COc1ccc(-c2cc(=O)c3c(O)cc(OC4O[C@H](CO)[C@@H](O)[C@H](O)C4(O)O)cc3o2)cc1</smiles><smiles>CCC1OC(Oc2cc(O)c3c(=O)cc(-c4ccc(OC)cc4)oc3c2)C(O)(O)C(O)C1(C)O</smiles><smiles>CC(O)(O)C(C)(O)O</smiles><smiles>CCCCC</smiles><smiles>OCC1CCC(O)CC1</smiles><smiles>COc1ccc(-c2cc(=O)c3c(O)cccc3o2)cc1</smiles>

Agastachin<smiles>CCC1CC(Oc2cc(O)c3c(=O)cc(-c4ccc(OC)cc4)oc3c2)C(OC(C)=O)[C@@H](O)[C@@H]1O</smiles>

Fig. 4 Non-volatile phenolic compounds from various Agastache species. a Phenylpropanoids. b Flavonoids 
$1.65 \mathrm{mg} / \mathrm{g}$ ), which is still a significantly lower amount compared to the yield of A. mexicana. Other flavonoids detected in these two species belonged mainly to various subclasses of aglycones, such as hesperetin, apigenin, salvigenin, kaempferol and quercetin, as well as $(+)$-catechin in $A$. mexicana (EstradaReyes et al. 2004; Suchorska-Tropiło and PióroJabrucka 2004; Ibarra-Alvarado et al. 2010), while apigenin, acacetin and 4',5-dihydroxy-3,3',7-trimethoxyflavone were in A. rugosa (Zakharova et al. 1980; Ishitsuka et al. 1982; Suchorska-Tropiło and PióroJabrucka 2004).

Glycosides other than tilianin were also obtained from the aerial parts of $A$. rugosa: linarin (7-Orutinoside of acacetin) and agastachoside (6" $-O$ acetyl-7- $\beta$-D-glucopyranosyloxy-5-hydroxy-4'-methoxyflavone) (Zakharova et al. 1980). Itokawa et al. (1981) were able to isolate not only two previously described flavonoids-acacetin (285 $\mathrm{mg}$ from $1 \mathrm{~kg}$ of herb) and tilianin (46 mg), but also two new compounds-210 $\mathrm{mg}$ of isoagastachoside (2"'-Oacetyl-7- $\beta$-D-glucopyranosyloxy-5-hydroxy-4'-methoxyflavone) and $19 \mathrm{mg}$ of a quite unique malonyl diglucosylflavonoid, named 'agastachin' (di-(6"-acacetin-7-glucosyl) malonate). A. pallida (Lindl.) Cory var. pallida (identified by the authors as $A$. barberi (B.L. Rob.) Epling from Brittonastrum section, was analyzed for surface flavonoids in a comparative study of Nepeta sp. and related genera. In this plant, four flavones were detected-luteolin, acacetin, cirsimaritin (5,4'-dihydroxy-6,7-dimethoxyflavone) and isothymusin (5,8,4'-trihydroxy-6,7-dimethoxyflavone) (Jamzad et al. 2003). No quantitative data were provided, however.

Different contents of flavonoids were observed in the aerial parts of $A$. rugosa, A. mexicana, and $A$. foeniculum, at three different times of harvest during blooming (Suchorska-Tropiło and Pióro-Jabrucka 2004). A high content of flavonoids (apigenin, quercetin) was observed at the beginning of the flowering period or else at full bloom, while their concentration declined as senescence set in. The largest amount of apigenin $(1.62 \mathrm{mg} / \mathrm{g})$ was reported for $A$. foeniculum and the smallest $(0.17 \mathrm{mg} / \mathrm{g})$ for $A$. rugosa at the beginning of blooming. At full bloom, there was also a significant amount of quercetin $(1.97 \mathrm{mg} / \mathrm{g})$ in A. foeniculum. The content of total hydroxycinnamic acids was not dependent on the term of harvest.

\section{Phenolic acids and lignans}

While low concentrations of flavonoids like acacetin and tilianin were reported in A. rugosa, RA content observed during the same experiment was markedly higher (Tuan et al. 2012). The highest amount of RA was detected in flowers, where its content was $48.43 \mu \mathrm{g} / \mathrm{g}$ d.w., as well as in roots $(30.97 \mu \mathrm{g} / \mathrm{g})$ and leaves $(22.14 \mu \mathrm{g} / \mathrm{g})$. The lowest content of RA was reported in stems $(9.14 \mu \mathrm{g} / \mathrm{g})$. Janicsak et al. (1999) compared rosmarinic and caffeic acid contents in 96 Lamiaceae taxa, including three Agastache species. The RA level was over four times higher than that of caffeic acid in all three species, and was as follows: A. mexicana-0.64 versus $0.15 \mathrm{mg} / \mathrm{g}, A$. urticifolia- 0.30 versus $0.05 \mathrm{mg} / \mathrm{g}$, and in $A$. foeniculum -0.27 versus $0.06 \mathrm{mg} / \mathrm{g}$ of rosmarinic and caffeic acids, respectively.

From the entire plant of $A$. rugosa, two lignansagastinol and agastenol-were isolated and characterized (Lee et al. 2002). Both compounds are built of three aromatic moieties (two phenylpropanoid and one benzoyl) substituted by three hydroxy- and two methoxy- groups in the same positions. Agastenol is $\left(7^{\prime} R, 8^{\prime} S\right)$-4-hydroxybenzoic acid 4-(hydroxy-3-methoxybenzylidene)-2-(4-hydroxy-3-methoxyphenyl)tetrahydrofuran-3-yl-methyl ester, whereas agastinol is a derivative with a saturated bond between carbons 7 and $8-\left(8 S, 7^{\prime} R, 8^{\prime} S\right)-4$-hydroxybenzoic acid 4-(4hydroxy-3-methoxybenzyl)-2-(4-hydroxy-3-methoxyphenyl)tetrahydrofuran-3-yl-methyl ester.

Non-volatile terpenoids and sterols

From A. rugosa roots, several new diterpenoids (examples in Fig. 5) were isolated and identified, such as a red-colored nor-abietanoid agastaquinone (Lee et al. 1995), and other oxidized abietanoids: agastol, dehydroagastol, isoagastol (Han 1987; Zou and Cong 1991), agastanone, and methylagastanol (Han 1987; Lee et al. 1994).

A. rugosa roots also contain several pentacyclic carboxylated and hydroxylated triterpenoids (Fig. 5) of oleanane-type (maslinic acid, oleanolic acid, 3-Oacetyl oleanolic aldehyde), ursane-type (corosolic acid) and the sterols $\beta$-sitosterol and daucosterol (Han 1987; Zou and Cong 1991; Estrada-Reyes et al. 2004). An ursane-type structure was also represented by ursolic acid isolated from aerial parts of $A$. 
Fig. 5 Structures of diterpenoids and pentacyclic triterpenes from Agastache<smiles>COC1=C(C(C)C)C(=O)c2c(O)cc3c(c2C1=O)C=CC(=O)C3(C)C</smiles>

Agastaquinone

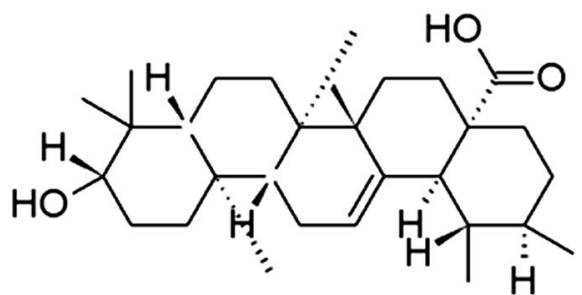

Ursolic acid

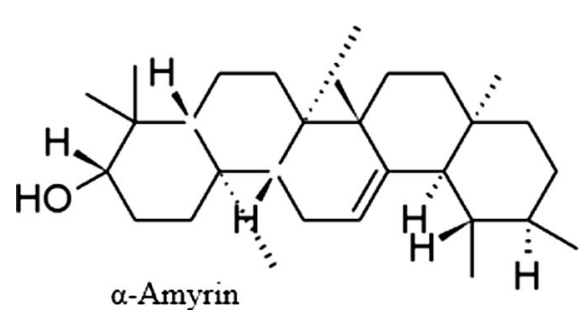<smiles>C=C(C)c1c(O)c(O)c2c(c1O)C(=O)C[C@H]1C(=C)[C@@H](C)CCC21C</smiles>

Dehydroagastol

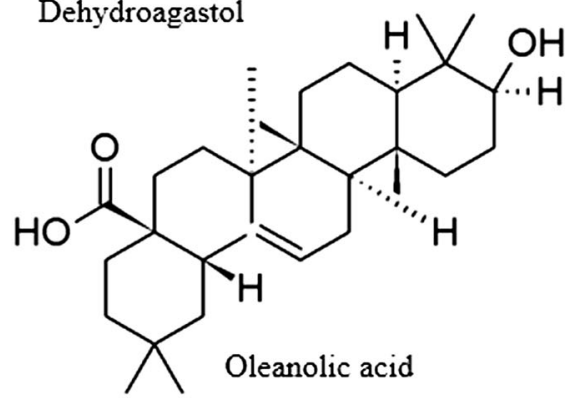

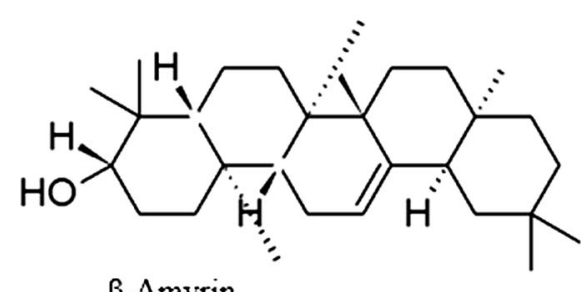

$\beta$-Amyrin

mexicana with a $0.33 \%$ yield (Verano et al. 2013). Both oleanane ( $\beta$-amyrin) and ursane (a-amyrin) triterpenoids were isolated from $A$. foeniculum aerial parts, together with numerous sterols and stanols (campesterol, campestanol, sitosterol, stigmasterol, stigmastanol: Fig. 5) (Ganeva et al. 1994; Zou and Cong 1991). Given the ubiquitous presence of both pentacyclic triterpenoids and sterols in plants, they can also be expected in other Agastache species, but there are no qualitative or quantitative data available so far.

The seed oil from A. rugosa studied for fatty acid composition consisted of $91 \%$ unsaturated fatty acids, of which $52 \%$ were C18:3 (linolenic acid), $27.5 \%$ were $\mathrm{C} 18: 2$ (linoleic acid) and $11.5 \%$ were monounsaturated C18:1 (oleic acid) acids (Zakharov et al. 1988).

As in every green plant, several carotenoids are also present in Agastache. Their quantitative analysis was performed in A. foeniculum and A. rugosa by means of RP-HPLC using a C30 column. $\beta$-Carotene was the most abundant followed by xanthophylls- lutein in amounts comparable to $\beta$-carotene and three less abundant-zeaxanthin, violaxanthin and antheraxanthin. A. rugosa contained larger amounts of each detected carotenoid-499.2 versus $260.9 \mu \mathrm{g} / \mathrm{g}$ of $\beta$ carotene and 277.1 versus $189.7 \mu \mathrm{g} / \mathrm{g}$ of lutein (Chae et al. 2013).

\section{Bioactivity of individual species as medicinal plants}

Of the three most important medicinal species, $A$. rugosa is the main object in most of the published bioactivity data (Table 3). A. rugosa is the only species native to East Asia, and it is an important herbal drug in Chinese, Korean and Japanese traditional medicine. As such, it has been frequently studied for various pharmacological activities in both in vitro and animal models.

In Traditional Chinese Medicine (TCM), there is an ambiguity as to the identity of Agastache rugosa as a herbal drug. The pinyin name-'huoxiang' 


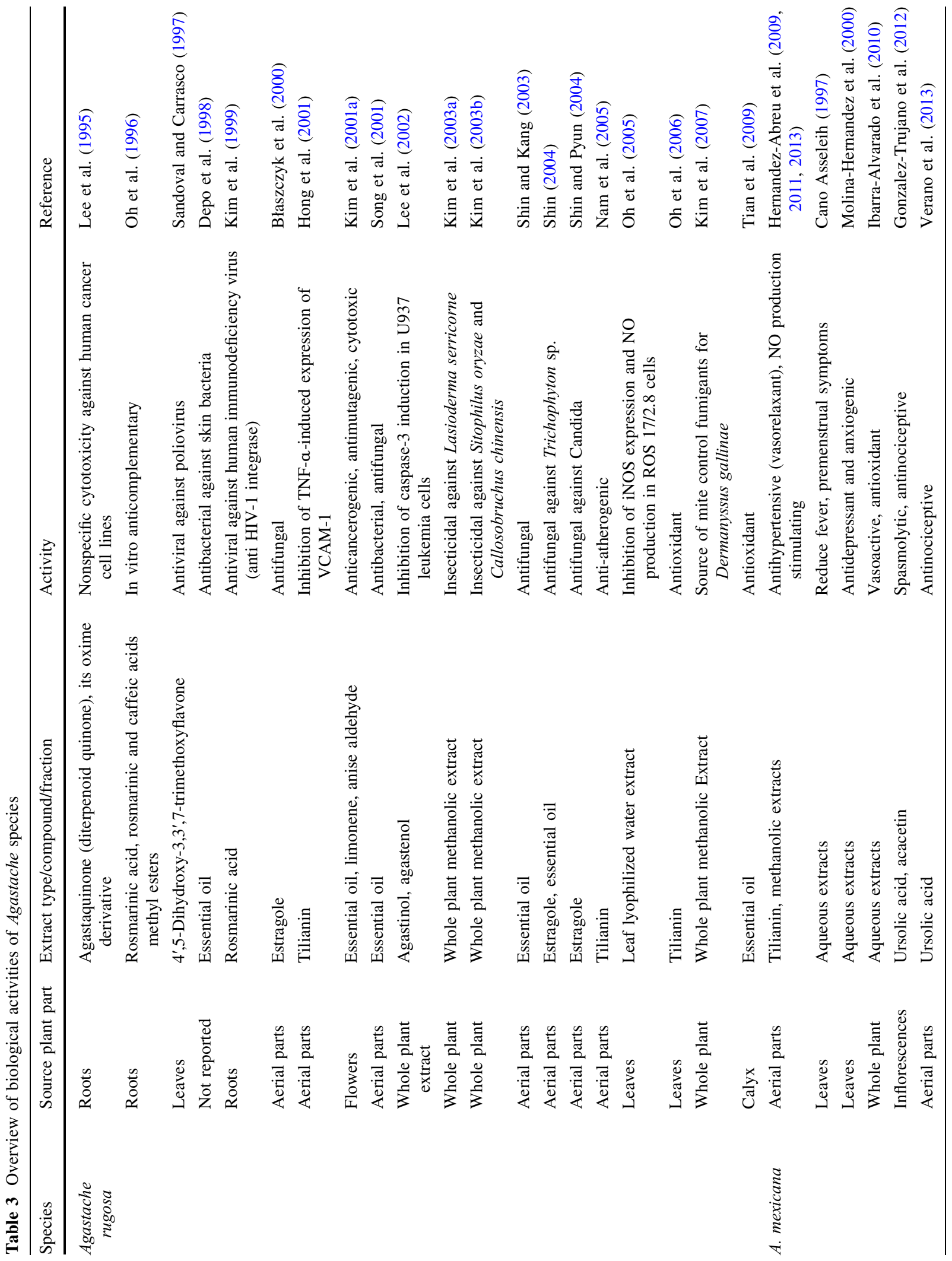


(藿香)—meaning Agastachis herba, can refer either to Agastache rugosa or to Pogostemon cablin (Blanco) Benth. (as Pogostemonis herba, 'Guang huoxiang'). The latter herb, also known as 'patchouli', originates from the south-east Asia (Malaysia and Indonesia), and is commonly used as a substitute for Agastache rugosa due to the similar functions defined by the TCM (Holmes 1997; Chen et al. 2008). Similarly, in traditional Japanese phytotherapy, both herbs are utilized under the name 'Kakko' (Itokawa et al. 1981). In fact, the chemical composition (and typical scent) of these plants is quite distinct (Holmes 1997; $\mathrm{Hu}$ et al. 2006; Wu et al. 2013). According to TCM theory, 'huoxiang' is classified among aromatic, dampdissolving herbs. It is said to dispel damp, release 'exterior' and 'summer-damp', relieve nausea and vomiting, and cure fungal infections. The taste and thermal properties of 'huoxiang' are pungent (acrid) and slightly warm, and the channel affiliations enter spleen, stomach and lung. The essential oil of A. rugosa is used against fever, headache, stomach pain, morning sickness (combined with Scutellaria) and other gastrointestinal disorders (Dung et al. 1996; Lee et al. 2004; Hou and Jin 2005).

A. mexicana has been used in Mexican folk medicine for the treatment of hypertension, stress and anxiety (Cano Asseleih 1997; Ibarra-Alvarado et al. 2010; Gonzalez-Trujano et al. 2012). Other North American species are also used as botanical drugs and food. Their usage by Native American people was summarized in the previous review (Fuentes-Granados et al. 1998). Briefly, most of applications refer to both the aerial parts and roots of A. foeniculum as a remedy against cough, fever and heart conditions, as well as externally in treating burns. Also, A. nepetoides leaves are used by Cayuga externally for treating burns (from poison ivy) and itching. Other folk medicinal species include: $A$. urticifolia, used in Nevada against swelling, gastric disorders and colds, A. pallidiflora used by the Navajo for the treatment of coughs and fevers, and A. scrophulariifolia roots, used by the Meskwaki as a diuretic decoction.

Antimicrobial activity

Antimicrobial activity is among the most frequently reported properties of essential oils from different medicinal plants. Agastache is no exception. However, 
the strength of antibacterial and antifungal activity was rather moderate in all the studied species.

Estragole isolated from A. rugosa was more efficient against human pathogenic fungi as a pure compound than as a crude essential oil. The antifungal activity of estragole was proven against Aspergillus niger, A. flavus, Trichoderma viride, Candida albicans, C. utilis, C. tropicalis, Cryptococcus neoformans, Trichophyton mucoides, T. tonsurans, and Blastoschizomyces capitatus (Shin 2004; Shin and Kang 2003). The minimum inhibitory concentration (MIC) obtained for purified estragole was $2.5 \mathrm{mg} / \mathrm{ml}$ for estragole and $5.0 \mathrm{mg} / \mathrm{ml}$ or more for the essential oil. These results are similar to those obtained from other Lamiaceae species, like Mentha spicata and Ocimum sanctum (MIC 2.5 and $5 \% \mathrm{v} / \mathrm{v}$, respectively), whereas the antimicrobial activity of Cymbopogon sp. (Poaceae) essential oils was reported to be approximately two orders of magnitude higher (MIC at $0.06 \%$ ) (Bansod and Rai 2008).

Despite these barely noteworthy values, interesting interactions were demonstrated between $A$. rugosa essential oil and pure estragole and two reference fungicidal antibiotics - the ketoconazole and amphotericin B. FIC indexes with ketoconazole were 0.19 for estragole and 0.16 for $A$. rugosa oil against $B$. capitatus, and 0.28-0.50 against Candida sp. (clearly indicating a synergistic interaction). In contrast, amphotericin B and estragole were antagonistic against Candida sp. (Shin and Pyun 2004).

A. foeniculum essential oil tested against Aspergillus sp. and Fusarium solani was markedly weaker than Iranian thyme (Thymus kotschyanus) and garden savory (Satureja hortensis) oils (Ownagh et al. 2010). Agastache oil had detectable fungistatic activity only at the highest concentrations -1 and $2 \mathrm{mg} / \mathrm{ml}$, whereas thyme and savory oils were fungicidal even below $125 \mu \mathrm{g} / \mathrm{ml}$. In brief, we can conclude that the existing data are not in favor of popular claims about the strong antimicrobial properties of essential oils from either Agastache or other, related herbs.

\section{Antiviral activity}

4-Methoxycinnamaldehyde from A. rugosa essential oil was reported to express antiviral activity against the human respiratory syncytial virus (Wang et al. 2009). This compound effectively inhibited the cytopathic effect of the respiratory syncytial virus in a human larynx carcinoma cell line $\left(\mathrm{IC}_{50}\right.$ of $0.055 \mu \mathrm{g} / \mathrm{ml}$ and a selectivity index of 898.2). It was able to inhibit viral entrance by interfering with viral attachment $\left(\mathrm{IC}_{50}\right.$ of $\left.0.06 \mu \mathrm{g} / \mathrm{ml}\right)$ and internalization ( $\mathrm{IC}_{50}$ of $0.01 \mu \mathrm{g} / \mathrm{ml}$ ). Moreover, 4-methoxycinnamaldehyde at $0.1 \mu \mathrm{g} / \mathrm{ml}$ had a high cytoprotective rate (90\%), while the same dose of Ribavirin (a prodrug used as a control substance) saw no activity of this kind. However, we must note that the 4-methoxycinnamaldehyde used in this study was purchased from a chemical company as a standard substance and was not obtained from A. rugosa. The authors mention this compound as an active principle of $A$. rugosa essential oil. This assumption was based on indirect citations from earlier publications, where phenylpropanoids such as estragole and cinnamaldehyde derivatives were studies as attractants of rootworm beetles (Metcalf and Lampman 1989). Hence, it is hardly possible to conclude that essential oil form $A$. rugosa can indeed become a practical source of this antiviral compound. In our own research using the GC-MS method on volatiles from this plant, 4methoxycinnamaldehyde was never detected (Zielińska et al. 2011).

An efficient anti-picornavirus compound was isolated from the leaves of $A$. rugosa. It was isolated and investigated under the code name Ro-09-0179 by a Japanese subsidiary of Roche (Ishitsuka et al. 1982). Chemically, it is 4',5-dihydroxy-3,3',7-trimethoxyflavone, also known as 'pachypodol', a tri-O-methyl ether of quercetin. This highly lipophilic flavonol selectively inhibited several human pathogenic RNA viruses, such as rhinovirus, coxsackievirus and poliovirus, acting on viral plus-strand RNA replication (at average $\mathrm{MIC}_{90}$ of $0.3 \mu \mathrm{g} / \mathrm{ml}$ ) (Ishitsuka et al. 1982). It specifically targets the Golgi complex and inhibits the processes associated with retrograde transport (Sandoval and Carrasco 1997).

Whether or not this promising compound has real therapeutic value and will be introduced as a drug or lead structure cannot be predicted at the moment.

HIV is another RNA human virus targeted by $A$. rugosa. Methanol extract, and from that isolated RA, inhibited HIV integrase enzymatic activity in vitro $\left(\mathrm{IC}_{50}\right.$ of RA was $10 \mu \mathrm{g} / \mathrm{ml}$ ) (Kim et al. 1999). However, it is rather difficult to expect the actual clinical relevance of RA as an anti-HIV compound. Its common occurrence in various plants and broad spectrum of activities renders it more of a model 
structure for further experiments on antiviral mechanisms than as an applicable preventive phytopharmaceutical.

\section{Anti-mutagenic and cytotoxic properties}

Essential oil from the flowers of A. rugosa was reported to express anti-mutagenic activity in a dosedependent manner when tested in Chinese hamster ovary AS52 cells. The AS52 cell line is a specially designed, genetically engineered, hypermutating in vitro system for testing mutations related to oxidative stress. The crude oil was more active (14, 68 and $75 \%$ inhibition of mutagenicity at concentrations $0.2,0.6$ and $1.0 \mathrm{~g} / \mathrm{l}$, respectively) than any of the three individual components (estragole $-11,16$ and $38 \%$; limonene 21, 30 and $43 \%$; anisaldehyde 8 , 49 and $63 \%$ ). Interestingly, the less abundant constituent of the oil-anisaldehyde was more potent than the two major compounds, estragole and limonene (Kim et al. 2001a). In the same study, the oil was relatively less cytotoxic to human liver cell cultures, and was inhibiting just below $12 \%$ of the untreated cell growth rate. On the other hand, a prominent inhibition of cancer cell line growth was observed, as well as the rapid augmentation of $\mathrm{T}$ and B cells' proliferation induced by the crude oil, which was not obtained by any of the three individual components. It is not possible to conclude from these results whether a synergy exists between the three oil components or whether the observed effects are caused by other minor, more active compounds.

A cytotoxic effect towards several cancer lines (lung, ovarian, melanoma, CNS and colon cancer) was also demonstrated by agastaquinone-a nonvolatile diterpenoid from $A$. rugosa roots (Lee et al. 1995). The efficacy expressed as $\mathrm{ED}_{50}$ differed for each cell line from $1.8 \mu \mathrm{g} / \mathrm{ml}$ (for neuronal cancer cells) to $12.8 \mu \mathrm{g} / \mathrm{ml}$, whereas cis-platin $\mathrm{ED}_{50}$ was $0.5-1.0 \mu \mathrm{g} / \mathrm{ml}$.

Interestingly, two lignans from the same plantagastinol and agastenol-caused quite different effects in leukemia cells U937, in which protection against etoposide-induced apoptosis was observed (Lee et al. 2002). Agastenol activity was close to the standard anti-apoptotic agent-pyrrolidine dithiocarbamate ( $\mathrm{IC}_{50} 11.4 \mu \mathrm{g} / \mathrm{ml}$ and $8.3 \mu \mathrm{g} / \mathrm{ml}$, respectively) -whereas agastinol was considerably less effective $\left(\mathrm{IC}_{50} 15.2 \mu \mathrm{g} / \mathrm{ml}\right)$. Although anti-apoptotic activity had been tested on a malignant cell line, it should be explored further as being potentially useful in degenerative and aging-related disorders.

The above results indicate the very promising potential of A. rugosa constituents in chemoprevention, which was demonstrated by in vitro cell-based assays. However, more investigations (including in vivo ones) are needed to confirm such properties. In particular, some minor but more active compounds from both essential oil and non-volatile fractions should be considered.

Antioxidant activity

Given the significance of Agastache sp. in traditional phytotherapy and economic botany in different regions, one might expect at least several papers describing a once very fashionable antioxidant activity. Quite surprisingly, unlike for many other related food and medicinal plants, little has been published about it.

Certainly, it can be assumed that the content of such potent antioxidants as RA and polyhydroxylated flavonoids should contribute to this type of activity. In this regard, a comparative mechanistic study using at least several complementary assays would be of particular interest. It should encompass different Agastache species and compounds isolated from them, followed by an attempt to elucidate the role of the individual constituents in the extracts' properties.

In one of the few in vivo studies that have been published so far, a TCM preparation containing essential oil from A. rugosa was remarkably efficient in alleviating heat stress symptoms. In pigs kept at $40{ }^{\circ} \mathrm{C}$, the herbal treatment reduced the malonyldialdehyde level and restored SOD and GPx activity to the control level. In a cell culture experiment involving separated components of the TCM preparation, the essential oil of $A$. rugosa herb was among the most efficient agents (at 100 and $200 \mu \mathrm{g} / \mathrm{ml}$ ) in improving antioxidant status after heat stress, but the differences were not significant (Guo et al. 2011). Another in vitro cell-based system in which A. rugosa has been improving an antioxidant marker is the standard monocyte/macrophage line RAW264.7 (Oh et al. 2006). Here, a concentrated decoction (hot water extract, lyophilized and dissolved at $28 \%$ concentration) efficiently induced the expression of 
HO-1 - one of the isoforms of heme oxygenase (HO). This effect was concomitant with decreased hydrogen peroxide cytotoxicity upon A. rugosa extract treatment. The suggested mechanism involves the protein kinase $\mathrm{G}$ pathway, evidenced by the use of PKG inhibitors, which partially counteracted the A. rugosa extract's cytoprotective activity. However, the contribution of direct $\mathrm{H}_{2} \mathrm{O}_{2}$ scavenging is also possible. Unfortunately, nothing is known about the particular extract constituents that may be responsible for this effect. According to $\mathrm{Oh}$ et al. (2006), it could be attributed to tilianin, but the authors did not check its content nor did they perform any standardization of the extract. Water extraction would most likely yield other phenolic compounds, such as caffeic acid derivatives, which could contribute to both direct antioxidant and heme oxygenase-activating mechanisms. The ability to scavenge reactive oxygen species - such as hydroxyl radicals-was also demonstrated in a screening study of 25 traditional Chinese herbs, among which a tincture (ethanol macerate) from Agastachis herba was moderately active with an $\mathrm{EC}_{50}$ of $4.4 \mu \mathrm{g} / \mathrm{ml}$ (Wang et al. 2006). Interestingly, Agastache extract was least reactive in a total polyphenol test $(29.3 \mathrm{mg} / \mathrm{g}$ gallic acid equivalents) of those with an $\mathrm{EC}_{50}$ was below $10 \mu \mathrm{g} / \mathrm{ml}$. Bearing in mind the inaccuracy of a 'total content of...' approach in bioactivity studies, it can be speculated that, in $A$. rugosa, there are other compounds at work, not just Folin-Ciocalteu reagentreducing agents.

\section{Cardiovascular and anti-inflammatory effects}

Tilianin is frequently regarded as a major bioactive compound, especially in two of the most popular species-A. rugosa and A. mexicana. Some studies have been performed using isolated tilianin, whereas in others it was a phytochemical marker in various extracts or fractions.

Both tilianin and extract from A. rugosa had a positive effect on the early stages of atherosclerosis pathophysiology (Hong et al. 2001). In experiments with mice on a high cholesterol diet, addition of $1 \%$ of $A$. rugosa methanol extract reduced the total plasma cholesterol levels (from $1065 \mathrm{mg} / \mathrm{dl}$ down to $986 \mathrm{mg} / \mathrm{dl}$ ). The cholesterol content of VLDL was lower, too, but the change was not statistically significant (Hong et al. 2001).
Treatment with tilianin $(0.05 \%$ in the diet $)$ resulted in the reduction (to $56.6 \%$ ) of the lesion area in the aortic sinuses of hyperlipidemic mice. However, the results showed no significant differences between tilianin treatment and a high cholesterol diet for the tested groups in terms of total cholesterol and HDL levels. Also, the triglyceride content was lower after tilianin supplementation in the tested groups of animals, although the results were not statistically significant (Nam et al. 2005).

However, pretreatment with tilianin significantly suppressed (80 and $74 \%$ at 10 and $100 \mu \mathrm{mol}$, respectively) the TNF-a-induced expression of vascular cell adhesion molecule-1 (VCAM-1) in the human umbilical vein endothelial cells (Hong et al. 2001). In murine peritoneal macrophages, tilianin inhibited NF- $\kappa$ B activation in a concentration-dependent manner (1-10 $\mu \mathrm{mol})$, causing a decrease of proinflammatory cytokines' (TNF- $\alpha$ and IL-1 $\beta$ ) mRNA levels (Nam et al. 2005).

Tilianin was also obtained from A. mexicana, which is actually a more abundant source of it. The antihypertensive properties of $A$. mexicana used in folk herbal medicine in Mexico are attributed to tilianin content (Hernandez-Abreu et al. 2009). In a comparative study of various solvent extracts prepared from herbs dried at different temperatures, vasorelaxant ex vivo activity correlated with the amount of tilianin (Hernandez-Abreu et al. 2011). However, the tilianin potency in relaxing rat aortic contractions was significantly weaker than the reference drug carbachol $\left(\mathrm{EC}_{50} 104 \mu \mathrm{g} / \mathrm{ml}\right.$ and $0.075 \mu \mathrm{g} /$ $\mathrm{ml}$, respectively).

The mechanisms of hypotensive and vasorelaxant properties involve the nitric oxide/cGMP pathway and potassium channel (Hernandez-Abreu et al. 2009). A hypotensive effect on both systolic and diastolic blood pressure was confirmed in vivo using a spontaneously hypertensive rat model in which the $\mathrm{ED}_{50}$ was $53.51 \mathrm{mg} / \mathrm{kg}$ body weight (compared to captopril $30 \mathrm{mg} / \mathrm{kg}$ ) (Hernandez-Abreu et al. 2013). In the same study, no toxicity was found in the mouse model up to the dose of $1 \mathrm{~g} / \mathrm{kg}$, which warrants further investigation at the clinical level. However, the overall efficacy of using $A$. mexicana as an anti-hypertensive remedy can be disputed, as demonstrated by the study of aqueous decoctions from 10 herbs (Ibarra-Alvarado et al. 2010). Of the seven herbs that evoked relaxation, A. mexicana extract was the second weakest $(24.9 \%$ relaxation of 
pre-contracted rat aortic segments), whereas four of them (Psittacanthus calyculatus, Dracocephalum moldavica, Prunus serotina, Chiranthodendron pentadactylon) reached more than $60 \%$ (Ibarra-Alvarado et al. 2010). This result actually agrees with those previously mentioned, where aqueous extracts were poor in tilianin. Thus, the most popular method for preparing herbal tea is rather unlikely to be efficient against cardiovascular conditions.

\section{Neurological activities}

Three different solvent extracts of $A$. mexicana subsp. xolocotziana exhibited anti-nociceptive activity, demonstrated in an animal study using rats and mice (Gonzalez-Trujano et al. 2012; Gonzalez-Ramirez et al. 2012). In a set of complementary tests, hexane, ethyl acetate and methanol extracts from macerated inflorescences were compared. As a result, all the extracts diminished nociception in experimental animals. Differences in the extracts' polarities were reflected by their composition and the kind of induced pain that was reduced in each test. Ethyl acetate extract (containing significant amounts of ursolic acid) was the most efficient in reducing behavioral responses to pain induced by formalin, especially in the inflammatory (second) phase, while hexane extract (non-polar compounds, like pulegone and oleanolic acid) decreased reactions to heat-induced pain. However, the inflammation symptoms caused by formalin were inhibited mainly by methanol extract, which is rich in flavonoids such as acacetin and tilianin. Acacetin, present in methanol extract $(14.9 \mathrm{mg} / \mathrm{g})$, showed the highest antinociceptive activity $\left(\mathrm{ED}_{50}\right.$ of $2 \mathrm{mg} / \mathrm{kg}$ ) while that for diclofenac was $12 \mathrm{mg} / \mathrm{kg}$ and that for ursolic acid was $3 \mathrm{mg} / \mathrm{kg}$. Spasmolytic response was also observed for acacetin at a concentration of $3.5 \mu \mathrm{mol}$. Furthermore, the same papers report a lack of gastric toxicity with high doses ( $1 \mathrm{~g} / \mathrm{kg}$ body weight) of extracts. The same extracts protected gastric mucosa against lesions caused by the oral administration of absolute ethanol. This study suggests a possible application of a complex preparation from this herb in alleviating various paincausing disorders, and confirms the typical ethnomedicinal use of $A$. mexicana in such conditions.

Likewise, $(R)-(+)$-pulegone from the essential oil of $A$. rugosa (syn. A. formosana) also exhibited antinociceptive activity against heat- and chemicallyinduced pain in mice, as well as CNS-depressing and anticonvulsant effects (de Sousa et al. 2011). It is not known what the cellular mechanisms of such activity are, but some structural resemblance to menthol (a widely-used monoterpene targeting several mediators in pain receptors, including kappa-opioid) could guide further research into pulegone and Agastache essential oil (Kamatou et al. 2013).

The aqueous extract of $A$. mexicana leaves exhibited antidepressant-like activity (Molina-Hernandez et al. 2000). The results of three different tests (an Elevated plus-maze test, a forced swimming test and an open field test) revealed the anxiogenic-like effect of $A$. mexicana extract rather than anxiolytic-like activity. In the elevated plus-maze test, $A$. mexicana water extract reduced open-arms exploration; the results of the forced swimming test also showed no antidepressant-like effect of the extract $(12.0 \mathrm{mg} / \mathrm{kg}$ body wt.), tested on rats' behavior using pentylenetetrazole (15 $\mathrm{mg} / \mathrm{kg}$ body wt.) and desipramine (32 $\mathrm{mg} / \mathrm{kg}$ body wt.) as control substances. However, when it was administrated together with desipramine, it increased the antidepressant-like effect of the latter, similar to the effect of pentylenetetrazole and desipramine co-administration. The open field test revealed no sedative effect of water extract of $A$. mexicana at the doses used. Again, the study is in partial agreement with traditional folk indications for this plant, but it also argues against its uncritical use as an anxiolytic remedy.

\section{Biocidal activity}

Somehow distinct from above described pharmacological and preventive properties are the pesticidal activities of various substances from the Agastache species. Some of the results presented below indicate the real applicative potential of as environmentally friendly, biodegradable crop- and foodstuff-protection products.

A. rugosa methanol extract obtained by maceration exhibits insecticidal activity against stored products pests, such as the beetle species Lasioderma serricorne (infesting tobacco products) (Kim et al. 2003a) as well as Sitophilus oryzae (rice weevil) and Callosobruchus chinensis (bean weevil) (Kim et al. 2003b).

The insecticidal properties against various stored product-infesting beetles were also evidenced by $A$. foeniculum essential oil. The pests efficiently targeted 
by estragole and 1,8-cineole-rich oil included: $L$. serricorne (saw-toothed grain beetle), Oryzaephilus surinamensis L. (a major pest of oilseeds, such as nuts, sunflowers and other foodstuffs), the red flour beetle (attacking mainly ground starch materials) Tribolium castaneum Herbst, and the lesser grain borer Rhyzopertha dominica F. (a pest of cereal grains) (Ebadollahi 2011; Ebadollahi et al. 2010, 2013). A. rugosa has also been suggested as one of the plants that may serve as an alternative source of mite control fumigants for Dermanyssus gallinae De Geer, an important blood-sucking poultry ectoparasite causing losses in flocks of egg-laying hens (Kim et al. 2007).

A. rugosa essential oil was also efficient in killing Meloidogyne incognita - a root-knot nematode. However, the tested plant represented a chemotype with over $50 \%$ methyleugenol and just $8.55 \%$ estragole (Li et al. 2013). Weak nematicidal activity was also exhibited by $A$. rugosa essential oil against the Pinewood nematode Bursaphelenchus xylophilus (Andres et al. 2012). A. mexicana methanol extract tested against parasitic flatworm (Fasciola hepatica) in a screening study on 19 herbal species from Mexico did not show any fasciolicide properties (Vera-Montenegro et al. 2008). With regard to crop protection, even the attractant properties of estragole and other phenylpropanoids from Agastache, could be utilized as semiochemical bait ingredients for controlling diabroticide rootworm beetles (Metcalf and Lampman 1989).
Herbal drug formulae

'Huoxiang' (Agastachis herba) is one of the 50 fundamental herbs used in TCM. It can be utilized as a single drug or as an ingredient in the multicomponent formulations most commonly used by TCM and other East Asian traditional phytotherapy systems (Table 4).

One noteworthy example of a multidrug formula containing A. rugosa is Gan-lu-xiao-du-dan, used in chronic hepatitis. This drug, consisting of 10 herbs, has been among the 10 most popular traditional Chinese medicines prescribed in Taiwan for hepatitis (Chen et al. 2008).

Another example of a Chinese patent medicine containing A. rugosa leaf water extract is Qiwei Baizhu Powder (QWBZP). Other ingredients in QWBZP include the roots of Panax ginseng, Atractylodes macrocephala, Pueraria lobata, Saussurea costus, Glycyrrhiza uralensis and a mushroom-Poria cocos (Wu et al. 2010). This herbal preparation is effective against HRV (human rotavirus) infection and has been studied in baby mice who suffered from diarrhea. In this study, QWBZP extract stimulated the gene transcription of several interleukins and IFN- $\gamma$ in intestinal mucosa epithelial cells, as well as modulated CD8 T cell subset density. The effect of the preparation was comparable to the standard antiviral drug Ribavirin.

There is also a traditional Korean formula-called 'Sopoongsan'-which contains A. rugosa among 12 ingredients. Sopoongsan is composed of water or

Table 4 Examples of herbal formulae containing Agastache rugosa

\begin{tabular}{|c|c|c|c|c|}
\hline Name of the formula & Plant material & Use/indications & Country & References \\
\hline Ya-hom & Whole plant & Stomach discomfort & Thailand & Suvitayavat et al. (2004) \\
\hline $\begin{array}{c}\text { One of the } 600 \text { types } \\
\text { of plant materials }\end{array}$ & Whole plant & Food uses & Taiwan & Chau and Wu (2006) \\
\hline Sopoongsan & Not reported & $\begin{array}{l}\text { Anti-inflammatory } \\
\text { Anti-microbial } \\
\text { Anti-allergy } \\
\text { Anticancer activity } \\
\text { In human skin }\end{array}$ & Korea & Lee et al. (2007) \\
\hline Gan-lu-xiao-du-dan & Not reported & Chronic hepatitis & Taiwan (Republic of China) & Chen et al. (2008) \\
\hline QWBZP & Leaves & $\begin{array}{l}\text { Infantile diarrhea caused } \\
\text { by rotavirus }\end{array}$ & China (P.R.C.) & $\mathrm{Wu}$ et al. (2010) \\
\hline
\end{tabular}


ethanol extracts from various plant species (besides A. rugosa, these are Nepeta japonica, Glycyrrhiza uralensis, Panax ginseng, Cnidium officinale, Peucedanum japonicum, Dendrobium nobile, Angelica koreana, Citrus unshiu, Magnolia officinalis), one mushroom species (Poria cocos) and one insect species-silk moth (Bombyx mori). This oriental medicinal prescription has been reported to exhibit anti-inflammatory, anti-microbial, anti-allergy and anticancer activity on human skin (Lee et al. 2007).

In Thailand, one of the folk herbal drug formulae used for the treatment of stomach discomfort is Yahom. It contains the entire plant of $A$. rugosa among 16 other plant substances (Suvitayavat et al. 2004). The ability of this formula to inhibit gastric acid secretion was evidenced in rats treated with histamine or carbachol (a synthetic acetylcholine derivative). Ya-hom treatment decreased pepsin and protein secretory rates and inhibited histamine-induced gastric mucosal blood flow. The effect was observed in a time- and dose-dependent manner. Moreover, Yahom enhanced visible gastric mucus secretion. The above effects support the use of this preparation against stomach discomfort (Suvitayavat et al. 2004). The research on composite preparations is not as advanced as on individual herbs or phytochemicals, due to its complexity and difficulties in reliable data analysis. However, the results obtained to date suggest the important contribution of A. rugosa to therapeutic properties of such preparations widely used in Asian phytomedicine.

\section{Biosynthesis of active compounds}

The molecular level of the biosynthesis of specialized metabolites of Agastache has so far been considered in only two published articles, both using A. rugosa. The earlier one (Maruyama et al. 2002) reported cloning and the functional expression of an enzyme responsible for the production of a monoterpene (limonene), while the more recent one (Tuan et al. 2012) described the expression of several key genes for early, committed steps of the biosynthesis of phenolic compounds.

The $d$-Limonene synthase gene from $A$. rugosa was cloned using a polymerase chain reaction (PCR) based on the highly conserved sequences among terpene synthases (TSs) (Maruyama et al. 2002).
Most of the synthase genes that had previously been discovered in various species of the Lamiaceae family encoded for the $l$-limonene synthases, and only one-from Schizonepeta tenuifolia-for the $d$ enantiomer (Maruyama et al. 2002). A. rugosa is a proper model for the characterization of $d$-limonene synthase, since the plant produces $d$-limonene and its downstream biosynthetic derivatives $l$-pulegone and $l$-isomenthone. The complete A. rugosa limonene synthase gene (Ar-lms) is a sequence of 2,077 nucleotides, and contains a $1,839 \mathrm{bp}$ translated region encoding 613 amino acids. The deduced amino acid sequence contains a putative plastid-targeting fragment at its $\mathrm{N}$-terminus. The recombinant $A$. rugosa limonene synthase gene was functionally expressed using an in vitro cell free-transcription/translation system. The recombinant protein yielded $d$-limonene as a single product of the enzymatic reaction from GPP (geranyl pyrophosphate). A. rugosa limonene synthase showed a high homology to the synthases ( $d$ - and l-limonene synthases) of closely-related species from the same plant family, indicating only a few amino acids' residues that are the responsible for the stereochemistry of the enzyme. The highest homology $(87.3 \%)$ was found with the $d$-limonene synthase from Schizonepeta tenuifolia, and the molecular weight $(60 \mathrm{kDa})$ of both proteins was identical. The deduced amino acid sequence of the $d$ limonene synthase gene from A. rugosa, exhibits a relatively high homology to the $l$-limonene synthase of other Lamiaceae species, such as: Mentha spicata (70.8\%), M. longifolia (70.6\%), Perilla frutescens $(62.8 \%)$ and P. citriodora (62.7\%). The comparison between $d$ - and l-limonene synthase amino acid sequences from several Lamiaceae species indicated 11 amino acid residues (four aromatic and seven acidic) as candidates for controlling the stereospecificity of the enzymatic reactions. The transcription of the genes involved in the early steps of phenylpropanoid biosynthesis was examined in A. rugosa using quantitative real-time PCR (Tuan et al. 2012). The expression patterns of these enzymes (phenylalanine ammonia-lyase (PAL), cinnamate 4-hydroxylase $(\mathrm{C} 4 \mathrm{H})$, 4-coumarate: CoA ligase (4CL), chalcone synthase (CHS) and chalcone isomerase (CHI)) were correlated to the RA and tilianin contents in different organs.

The cDNA of two genes encoding the enzymes (chalcone synthase and chalcone isomerase) involved 
in the biosynthesis of tilianin in A. rugosa were also isolated and characterized (Tuan et al. 2012). CHS and CHI have demonstrated a high homology with respect to the enzymes of other species. For instance, the A. rugosa CHS amino acid sequence has a $95 \%$ identity and $98 \%$ similarity with Perilla frutescens CHS (Lamiaceae), a $95 \%$ identity and $98 \%$ similarity with Solenostemon scutellarioides CHS (Lamiaceae), a $93 \%$ identity and $96 \%$ similarity with Misopates orontium CHS (Plantaginaceae), and a $92 \%$ identity and $96 \%$ similarity with Mazus pumilus CHS (Phrymaceae). The results of homology analysis indicated four A. rugosa amino acid residues defined for the active sites (Cys 164, Phe 215, His 303 and Asn 336) that are conserved in all the identified chalcone synthases. The A. rugosa chalcone isomerase was highly homologous to Perilla frutescens $\mathrm{CHI}$ (79\% identity and $88 \%$ similarity), Scutellaria baicalensis CHI-Lamiaceae (78 and $89 \%$ similarity), Camelia sinensis $\mathrm{CHI}-$ Theaceae (75\% identity and $88 \%$ similarity), and Dianthus caryophyllus $\mathrm{CHI}-$ Caryophyllaceae (74\% identity and $87 \%$ similarity). In the A. rugosa $\mathrm{CHI}$, four residues were found (Thr 60, Tyr 118, Asn 125 and Ser 202) that had already been known as active sites of chalcone isomerases.

The comparative analysis of the gene transcription level of biosynthetic enzymes and the content of secondary metabolites (acacetin, tilianin and RA) showed the constitutive expression of the genes in all organs. The highest transcript levels of $A r P A L$ and $\mathrm{Ar} 4 \mathrm{CL}$ were found in leaves, whereas $\mathrm{ArC} 4 \mathrm{H}, \mathrm{ArCHS}$ and $\mathrm{ArCHI}$ reached their highest expression in flowers. In roots, all five genes were expressed at a relatively low level (Tuan et al. 2012). These results reveal a complex regulation mechanism of the biosynthesis of $A$. rugosa flavonoids (acacetin, tilianin) and RA. The highest expression (= transcript accumulation) of $A$. rugosa $P A L$ and $4 C L$ in leaves as well as $C 4 H$ in flowers corresponded to a relatively high content of RA in those plant organs. Yet, a significant amount of RA was present in the roots, where the transcript levels of $P A L, C 4 H$ and $4 C L$ were low. Mechanisms for the allocation of specific metabolites and metabolite fluxes within the plant body require more studies, which should focus especially on more downstream biosynthetic enzymes and genes, as well as on possible transport between tissues and organs.
Agastache in in vitro cultures and the production of secondary metabolites

Plant in vitro cultures have been applied mainly to $A$. rugosa and only rarely to other species (two reports on A. foeniculum) for such purposes as micropropagation (Mazur and Reshetnikov 2005; Kayani et al. 2013; Zielińska et al. 2011) and as a model system for studying the biosynthesis regulation of volatile (Menghini et al. 1992; Shin et al. 2001; Zielińska et al. 2011) and non-volatile specialized metabolites, as well as the efficient production of desired compounds such as RA (Mazur et al. 2008; Xu et al. 2008; Kim et al. 2013).

Different organ and tissue cultures were initiated, including callus from various explants, suspension cell cultures and organs (shoots and roots). Hairy roots were also induced by transformation with Agrobacterium rhizogenes.

For the in vitro shoot multiplication of A. rugosa, 6-bezylaminopurine was the favored cytokinin for inducing a morphogenetic response, and stem nodal segments were the optimal explants for forming multiple shoots (Mazur and Reshetnikov 2005; Zielińska et al. 2011). Furthermore, the total shoot number per explant was higher when the proliferation medium was supplemented with a natural auxin (indole-3-acetic acid) rather than a synthetic auxinic herbicide (picloram) (Zielińska et al. 2011).

A micropropagation protocol using shoot multiplication from nodal explants, followed by rooting and acclimation, was also established for $A$. foeniculum (syn. A. anisata) (Kayani et al. 2013). As with A. rugosa, the best performance (eight shoots per explant) was achieved on a BA- and IAA-supplemented MS medium. Great diversity was observed in the headspace volatile metabolites' profiles in $A$. rugosa shoot cultures (Zielińska et al. 2011). The composition of the volatiles emitted from the shoots growing on media supplemented with exogenous plant growth regulators was significantly different from the intact plant phytochemical profile. Under in vitro conditions, monoterpenes such as limonene, pulegone, menthone and isomenthone predominated, whereas estragole was present only in trace amounts. The estragole content in in vitro-germinated seedlings and intact plants was significantly higher (21 and $95 \%$, respectively). On the other hand, the content of individual monoterpenes also varied 
between different hormonal treatments. For example, pulegone constituted $12.2-92.7 \%$ of the total headspace volatiles analyzed by SPME-GC-MS, isomenthone from 0.1 to $26.4 \%$, and $\alpha$-pinene (which was absent from conventionally grown plants) from 1.6 to $25.9 \%$. These results show that in vitro conditions can greatly influence the proportions between phenylallyls and monoterpenes, as well as between different monoterpenes (Zielinska et al. 2011). In contrast, the shoot cultures of A. foeniculum produced mainly estragole but only traces of another volatile phenylpropanoid-trans-anethole. The culture media's supplementation with the precursor of a general phenylpropanoid pathway-shikimic acidenhanced the concentration of methyl chavicol, and several pigments (i.e., chlorophyll a, chlorophyll b and carotenoids). No direct correlation between estragole content and pigment concentration was observed (Menghini et al. 1992).

In a suspension cell culture of $A$. rugosa initiated from a leaf-derived callus maintained in the dark, hydrocarbons and sesquiterpenes were mostly identified, whereas elicitation with methyl jasmonate or jasmonic acid (both at $100 \mu \mathrm{M}$ ) and illumination with white light resulted in more monoterpenes and a low amount of estragole (0.58\%) (Shin et al. 2001). The results of another study (Kim et al. 2001b) also show that non-differentiated cells differ in the volatile metabolite production profile. In the suspension cultures also obtained from leaf calluses, 3-hydroxy-2-butanone was the most abundant compound, followed by 2,4,5-trimethyl-3-oxazoline, 1,2,4-trimethylbenzene and 1,3-butanediol. Estragole and other typical compounds of the species were not detected. In plants regenerated via in vitro cultures, the content of secondary metabolites (such as total phenolics, flavonoids, acacetin and tannins) also deviated from conventionally grown plants (Mazur et al. 2008).

A. rugosa suspension cultures maintained on media containing 2,4-D $(0.5 \mathrm{mg} / \mathrm{l})$ and kinetin $(0.1 \mathrm{mg} / \mathrm{l})$ produced only low amounts of RA (Kim et al. 2001c). The highest content of RA (slightly exceeding $0.4 \mathrm{mg} / \mathrm{g}$ d.w.) was obtained on the eighteenth day during the stationary phase of the culture in the cells, but not in the culture medium. Better results for RA production in suspension cultures of $A$. rugosa were obtained by treatment with benzothiadiazole combined with a yeast elicitor.
The experiments with elicitation enhanced the production of RA in the suspension cells by a factor of 11.4 , but the maximum content of this compound reached only $5 \mathrm{mg} / \mathrm{g}$ of dry weight. The benzothiadiazole alone had no effect on RA production. However, in later experiments similar suspension cultures were able to accumulate much higher quantities of RA. The best cell growth $(7.0 \mathrm{~g} / \mathrm{l})$ and RA production $(10.7 \mathrm{mg} / \mathrm{g}$ d.w.) were observed on a MS medium supplemented with BAP $(0.1 \mathrm{mg} / \mathrm{l})$ and with 2,4-D (2 mg/l). A slightly higher content for the RA (11.5 mg/g d.w.) was achieved after culturing the suspension cells on B5 (Xu et al. 2008).

In the most recent report, the elicitation of cell cultures with methyl jasmonate $(50 \mu \mathrm{M})$ resulted in a more than five-times higher accumulation of RA, up to $36.58 \mathrm{mg} / \mathrm{g}$ (Kim et al. 2013), which was similar to the value obtained-for example-in Lavandula vera (33.2 g/l d.w.) (Georgiev et al. 2004).

A metabolomic and transcript analysis of the key biosynthetic genes encoding the enzymes for early committed steps in phenylpropanoid metabolism, such as phenylalanine ammonia lyase $(A r P A L)$, cinnamate-4-hydroxylase $(A r C 4 H)$, and 4-coumarate: coenzyme-A (CoA) ligase $(A r 4 C L)$, was published recently by Kim et al. (2013). The experiment using $A$. rugosa cell cultures elicited with methyl jasmonate demonstrated that both phenolic acids ( $p$-coumaric, $p$-hydroxybenzoic, ferulic, rosmarinic) and precursors for the phenylpropanoid biosynthetic pathway (such as aromatic amino acids and shikimate) were induced as a response to MeJA treatment. The increased RA accumulation in the elicited cells might be due to the activation of the phenylpropanoid genes ArPAL, ArC4H and $A r 4 C L$, whose transcripts were increased by a factor of 9.2, 7.8 and 7.4, respectively (Kim et al. 2013). Hairy roots were induced by the infection of the leaves and stem sections of A. rugosa with the Agrobacterium rhizogenes B1000 strain. The maximum biomass growth of $14.1 \mathrm{~g} / \mathrm{l}$ in a basal liquid MS medium was achieved after 2 weeks of culture. In the hairy root cultures, the RA content reached $116.3 \mathrm{mg} / \mathrm{g}$ dry weight after 14 days of culture (Lee et al. 2008). It was significantly higher than the best results obtained from cell cultures and the roots of $A$. rugosa. The efficiency of this system is comparable to other representatives from Lamiaceae, like Hyssopus officinalis, Ocimum basilicum, Salvia miltiorrhiza and S. officinalis, usually reaching 
between 5 and $15 \%$ of dry weight (reviewed by Park et al. 2008).

Closing remarks and future outlook

All the above-mentioned findings suggest the importance of A. rugosa for East Asian traditional medicine, which can be expected to extend to other regions, similar to the already more popular herbs from Lamiaceae. Two American species-currently more common as ornamentals—-should also be considered as prospective phytomedicines. For this to occur, more research is needed, both on whole crude drugs and on purified fractions and individual compounds.

The role of individual components in the determination of medicinal properties is yet to be elucidated and the mechanisms of action verified. This also applies to multi-herb formulas (most commonly administered in traditional medicine) in order to understand the contribution of each constituent as well as any potentially synergistic or additive relationships.

Another question concerns how genetic diversity, already existing in the form of many ornamental varieties, affects phytochemical composition and medicinal properties, as exemplified by the case of A. mexicana subspecies (Estrada-Reyes et al. 2004).

Issues relating to the diversity and variability of essential oil composition and yield must be resolved as a prerequisite for proper quality management and standardization procedures. In this respect, the biotechnological approach may become the appropriate solution. It applies equally to the composition of nonvolatile phytochemicals, such as tilianin and other flavones, phenolic acids, rare diterpenoids and triterpenoids. The latter two groups-except for ursolic acid-have not been sufficiently studied in terms of their bioactivity or the possibility of obtaining applicable amounts for pharmaceutical use. These compounds are also promising as biological pesticides, especially in the protection of stored crops attacked by pest invertebrates.

In the near future, we will most likely witness a flurry of publications dealing with various aspects of bioactivity and molecular phytochemistry in Agastache. We hope that this review will inspire more researchers to consider those beautiful and healthy plants worth studying, as well as funding agencies in supporting such research.
Acknowledgments This article is based on the work supported by grant from the National Research Center (NCN) within the Preludium scheme No. 2011/01/N/NZ4/ 01152.

Open Access This article is distributed under the terms of the Creative Commons Attribution License which permits any use, distribution, and reproduction in any medium, provided the original author(s) and the source are credited.

\section{Referencess}

Andres MF, Gonzalez-Coloma A, Sanz J et al (2012) Nematicidal activity of essential oils: a review. Phytochem Rev 11:371-390

Ayers G, Widrlechner MP (1994) The genus Agastache as bee forage: a historical perspective. Am Bee J 134(5):341-348

Bansod S, Rai M (2008) Antifungal activity of essential oils from Indian medicinal plants against human pathogenic Aspergillus fumigatus and A. niger. World J Med Sci 3 (2):81-88

Błaszczyk T, Krzyżanowska J, Lamer-Zarawska E (2000) Screening for antimycotic properties of 56 Traditional Chinese Drugs. Phytother Res 14:210-212

Bruni R, Bianchi A, Bellardi MG (2007) Essential oil composition of Agastache anethiodora Britton (Lamiaceae) infected by cucumber mosaic virus (CMV). Flavour Fragr J 22:66-70

Bye R, Linares E, Ramamoorthly TP et al (1987) Agastache mexicana subsp. xolocotziana (Lamiaceae), a new taxon from the Mexican medicinal plants. Phytologia 62:157-163

Cano Asseleih L (1997) Flora medicinal de Veracruz. I. Inventario etnobotanico. Universidad Veracruzana, Xalapa, Veracruz, Mexico

Cantino PD, Harley RM, Wagstaff SJ (1992) Genera of Labiatae: status and classification. In: Harley RM, Reynolds T (eds) Advances in Labiatae Science. Royal Botanic Gardens, Kew, UK

Chae YA, Hyun-Choong O, Song JS (2005) Variability of the volatile composition of Agastache rugosa in South Korea. Acta Hortic 675:59-64

Chae SC, Lee SW, Kim JK et al (2013) Variation of carotenoid content in Agastache rugosa and Agastache foeniculum. Asian J Chem 25(8):4364-4366

Charles DJ, Simon JE, Widrlechner MP (1991) Characterization of essential oil of Agastache species. J Agric Food Chem 39(11):1946-1949

Charles DJ, Simon JE, Glowacki C et al (1992) The major essential oil constituents of Agastache spp. Acta Hortic 306:327

Chau CF, Wu SH (2006) The development of regulations of Chinese herbal medicines for both medicinal and food uses. Trends Food Sci Tech 17:313-323

Chen FP, Kung YY, Chen YC et al (2008) Frequency and pattern of Chinese herbal medicine prescriptions for chronic hepatitis in Taiwan. J Ethnopharmacol 117:84-91

Corrigan EE (2002) Agastache scrophulariifolia (Willd.) Kutze Purple Giant Hyssop. New England Plant Conservation Program. New England Wild Flower Society 180:1-22 
Dapkevicius A, Venskutonis R, Van Beek TA et al (1998) Antioxidant activity of extracts obtained by different isolation procedures from some aromatic herbs grown in Lithuania. J Sci Food Agric 77:140-146

De Sousa DP, Nobrega FF, de Lima MR et al (2011) Pharmacological activity of (R)-(+)- pulegone, a chemical constituent of essential oils. Z Naturforsch $66 \mathrm{c}(7-8): 353-$ 359

Depo Y, Chaumont J-P, Millet J (1998) Antibacterial activity on skin and chemical composition of the volatile oils from Agastache rugosa and Pogostemon cablin. J Microbiol 18:1-4. http://en.cnki.com.cn/Article_en/CJFDTOTAL-WSWX199 804000.htm

Dragland S, Senoo H, Wake K et al (2003) Several culinary and medicinal herbs are important sources of dietary antioxidants. J Nutr 133:1286-1290

Dung NX, Cu LD, Thai NH et al (1996) Constituents of the leaf and flower oils of Agastache rugosa (Fisch. et Mey) O. Kuntze from Vietnam. J Essent Oil Res 8:135-138

Ebadollahi A (2011) Chemical constituents and toxicity of $A$ gastache foeniculum (Pursh) Kuntze essential oil against two stored-product insect pests. Chil J Agr Res 71(2):212217

Ebadollahi A, Safaralizadeh MH, Pourmirza AA et al (2010) Toxicity of essential oil of Agastache foeniculum (Pursh) kuntze to Oryzaephilus surinamensis L. and Lasioderma serricorne F. J Plant Prot Res 50(2):215-219

Ebadollahi A, Khosravi R, Sendi JJ et al (2013) Toxicity and physiological effects of essential oil from Agastache foeniculum (Pursh) Kuntze against Tribolium castaneum Herbst (Coleoptera: Tenebrionidae) larvae. Ann Rev Res Biol 3(4):649-658

Estrada-Reyes R, Hernandez EA, Garcia-Argaez A et al (2004) Comparative chemical composition of Agastache mexicana subsp. mexicana and $A$. mexicana subsp. xolocotziana. Biochem Syst Ecol 32:685-694

Fuentes-Granados R, Widrlechner MP, Wilson LA (1998) An overeview of Agastache research. J Herbs Spices Med Plants 6(1):69-97

Fujita SI, Fujita Y (1973) Miscellaneous contributions to the essential oils of plants from various territories XXXIII. Essential oil of Agastache rugosa 0. Kuntze. Yakugaku Zasshi 93:1679-1681

Ganeva Y, Tsankova E, Parvanova K et al (1994) Triterpenoids from Agastache foeniculum. Chimie 47:49-51

Georgiev M, Pavlov A, Ilieva M (2004) Rosmarinic acid production by Lavandula vera MM cell suspension: the effect of temperature. Biotechnol Lett 26:855-856

Gong H, Zhou X, Zhu M et al (2012a) Constituents of essential oil isolated from the dried flower and leaf of Agastache rugosa (Fisch. et Mey) from Xinjiang, in China. J Essent Oil Bear Pl 15(4):534-538

Gong HY, Ding JB, Zhu M et al (2012b) Phytochemical investigation and antimicrobial activity of Agastache rugosa growing in Xinjiang, China. Asian J Chem 24 (7):2961-2964

Gonzalez-Ramirez A, Gonzalez-Trujano ME, Pellicer F et al (2012) Antinociceptive and anti- inflammatory activities of the Agastache mexicana extracts by using several experimental models in rodents. $\mathrm{J}$ Ethonopharmacol 142:700-705
Gonzalez-Trujano ME, Ventura-Martinez R, Chavez M et al (2012) Spasmolytic and antinociceptive activities of ursolic acid and acacetin identified in Agastache mexicana. Planta Med 78(08):793-796

Guo KJ, Xu SF, Yin P et al (2011) Active components of common traditional Chinese medicine decoctions have antioxidant functions. J Anim Sci 89:3107-3115

Han DS (1987) Triterpenes from the root of Agastache rugosa. Kor. J Pharmacogn 18:50-53

Hernandez-Abreu O, Castillo-Espana P, Leon-Rivera I et al (2009) Antihypertensive and vasorelaxant effects of tilianin isolated from Agastache mexicana are mediated by NO/cGMP pathway and potassium channel opening. Biochem Pharmacol 78:54-61

Hernandez-Abreu O, Duran-Gomez L, Best-Brown R et al (2011) Validated liquid chromatographic method and analysis of content of tilianin on several extracts obtained from Agastache mexicana and its correlation with vasorelaxant effect. J Ethnopharmacol 138:487-491

Hernandez-Abreu O, Torres-Piedra M, Garcia-Jimenez S et al (2013) Dose-dependent antihypertensive determination and toxicological studies of tilianin isolated from Agastache mexicana. J Ethnopharmacol 146:187-191

Hersch-Martinez P (1997) Medicinal plants and regional traders in Mexico: physiographic differences and conservational challenge. Econ Bot 51(2):107-120

Holmes P (1997) Patchouli. The colours within the darkness. Int J Aromather 8(1):18-22

Hong JJ, Choi JH, Oh SR et al (2001) Inhibition of cytokineinduced vascular cell adhesion molecule-1 expression; possible mechanism for anti-atherogenic effect of Agastache rugosa. FEBS Lett 495:142-147

Hou JP, Jin Y (2005) The healing power of Chinese herbs and medicinal recipes. Integrative Healing Press-Haworth Press Inc. Binghampton, NY, USA

$\mathrm{Hu}$ LF, Li SP, Cao H et al (2006) GC-MS fingerprint of Pogostemon cablin in China. J Pharm Biomed Anal 42:200-206

Ibarra-Alvarado C, Rojas A, Mendoza S et al (2010) Vasoactive and antioxidant activities of plants used in Mexican traditional medicine for the treatment of cardiovascular diseases. Pharm Biol 48:732-739

Ishitsuka H, Ohsawa C, Ohiwa T et al (1982) Antipicornavirus flavone Ro 09-0179. Antimicrob Agents Chemotherapy 22:611-616

Itokawa H, Suto K, Takeya K (1981) Structures of isoagastachoside and agastachin, new glucosylflavones isolated from Agastache rugosa. Chem Pharm Bull 29:1777-1779

Jamzad Z, Grayer RJ, Kite GC et al (2003) Leaf surface flavonoids in Iranian species of Nepeta (Lamiaceae) and some related genera. Biochem Syst Ecol 31:587-600

Janicsak G, Mathe I, Mikklosy-Vari V et al (1999) Comparative studies of the rosmarinic and caffeic acid contents of Lamiaceae species. Biochem Syst Ecol 27:733-738

Kamatou GP, Vermaak I, Viljoen AM et al (2013) Menthol: a simple monoterpene with remarkable biological properties. Phytochemistry 96:15-25

Kayani HA, Khan S, Naz S et al (2013) Micropropagation of Agastache anisata using nodal segments as explants and cytotoxic activity of its methanolic extracts. Pak J Bot 45 (6):2105-2109 
Kim HK, Lee HK, Shin CG et al (1999) HIV integrase inhibitory activity of Agastache rugosa. Arch Pharm Res 22(5):520-523

Kim MK, Chung WT, Kim YK et al (2001a) The effect of the oil of Agastache rugosa O. Kuntze and three of its components on human cancer cell lines. J Essent Oil Res 13 (3):214-218

Kim TH, Joong HS, Hyung HB et al (2001b) Volatile flavour compounds in suspension culture of Agastache rugosa Kuntze (Korean mint). J Sci Food Agric 81:569-575

Kim HK, Oh SR, Lee HK et al (2001c) Benzothiadiazole enhances the elicitation of rosmarinic acid production in a suspension culture of Agastache rugosa O. Kuntze. Biotechnol Lett 23:55-60

Kim SI, Park C, Ohh MH et al (2003a) a) Contact and fumigant activities of aromatic plant extracts and essential oils against Lasioderma serricorne (Coleoptera: Anobiidae). J Stored Prod Res 39:11-19

Kim SI, Roh JY, Kim DH et al (2003b) Insecticidal activities of aromatic plant extracts and essential oils against Sitophilus oryzae and Callosobruchus chinensis. J Stored Prod Res 39:293-303

Kim SI, Na YE, Yi JH et al (2007) Contact and fumigant toxicity of oriental medicinal plant extracts against Dermanyssus gallinae (Acari: Dermanyssidae). Vet Parasitol 145:377-382

Kim YB, Kim JK, Uddin MR et al (2013) Metabolomics analysis and biosynthesis of rosmarinic acid in Agastache rugosa Kuntze treated with methyl jasmonate. PLoS ONE 8(5):e64199

Lee HK, Byon SJ, Oh SE et al (1994) Diterpenoids from the roots of Agastache rugosa and their cytotoxic activities. Korean J Pharmacogn 25:319-327

Lee HK, Oh SR, Kim JI et al (1995) Agastaquinone, a new cytotoxic diterpenoid quinine from Agastache rugosa. J Nat Prod 58:1718-1721

Lee CH, Kim HN, Kho YE (2002) Agastinol and agastenol, novel lignans from Agastache rugosa and their evaluation in an apoptosis inhibition assay. J Nat Prod 65:414-416

Lee HK, Oh SR, Ahn KS et al (2004) Agastache rugosa extract and composition containing tilianin isolated and purified from said extract having anti-inflamatory activity and anti-atherogenic activity. US Patent Application Publication, US 2004/0071792 A1

Lee JY, Park TS, Son JH et al (2007) Verification of biological activity of irradiated Sopoongsan, an oriental medicinal prescription, for industrial application of functional cosmetic material. Radiat Phys Chem 76:1890-1894

Lee SY, Xu H, Kim YK et al (2008) Rosmarinic acid production in hairy root cultures of Agastache rugosa Kuntze. World J Microbiol Biotechnol 24:969-972

Li HQ, Liu QZ, Liu ZL et al (2013) Chemical composition and nematicidal activity of essential oil of Agastache rugosa against Meloidogyne incognita. Molecules 18:4170-4180

Lim SS, Jang JM, Park WT et al (2013) Chemical composition of essential oils from flower and leaf of korean mint, $A$ gastache rugosa. Asian J Chem 25:4361-4363

Lint H, Epling C (1945) A revision of Agastache. Am Midl Nat 33:207-230

Mallavarapu GR, Kulkarni RN, Baskaran K et al (2004) The Essentials oil composition of anise hysop grown in India. Flavour Fragr J 19:351-353
Manning ME, Padgett WG (1991) Riparian community type classification for the Humboldt and Toiyabe National Forests, Nevada and Eastern California. U.S. Department of Agriculture Forest Service, Intermountain Region, Ecology and Classification Program, Odgen, Utah, USA

Maruyama T, Saeki D, Ito M et al (2002) Molecular cloning, functional expression and characterization of $d$-Limonene synthase from Agastache rugosa. Biol Pharm Bull 25 (5):661-665

Mazur TV, Reshetnikov VN (2005) Cultivation of Agastache rugosa (Fisch. et Mey) Kuntze in vitro. Весці Нацыянальнай акадэміі навук Беларусі. Серыя біялагічных навук (Vestsi Natsyyanal'naj Akademii Navuk Belarusi ser. Biyalagichnykh navuk) 3:5-9

Mazur TV, Reshetnikov VN, Fomenko TI (2008) Vtorochnye metabolity rasteniy-regenerantov Agastache rugosa. (Secondary metabolites of regenerant plants of Agastache rugosa (Fish. et Mey). Весці Нацыянальнай акадэміi навук Беларусі. Серыя біялагічных навук (Vestsi Natsyyanal'naj Akademii Navuk Belarusi ser. Biyalagichnykh navuk) 4:5-9

Mazza G, Kiehn FA (1992) Essential oil of Agasatche foeniculum, a potential source of methylchavicol. J Essent Oil Res 4(3):295-299

Menghini A, Capuccella M, Pagiotti R et al (1992) Pigment content and methyl chavicol production in Agastache foeniculum Kuntze cultured in vitro. J Essent Oil Res 4 (5):483-486

Metcalf RL, Lampman RL (1989) Estragole analogues as attractants for corn rootworms (Coleoptera: Chrysomelidae). J Econ Entom 82:123-129

Mo J, Ma L (2011) Volatile oil of Herba Agastache in various growth periods and different parts by GC-MS. Chin J Pharm. http://en.cnki.com.cn/Article_en/CJFDTOTAL-ZHOU201 104011.htm. Cited 31 Dec 2013

Mo JX, Jang C, Zhang XY (2009) Studies on characteristics of volatile oil and micro identification between Herba Pogostemonis and Herba Agastache rugosae. J Chin Med Mater 32(11):1675-1677

Molina-Hernandez M, Tellez-Alcantara P, Martinez E (2000) Agastache mexicana may produce anxiogenic-like actions in the male rat. Phytomedicine 7(3):199-203

Nam KW, Kim J, Hong JJ et al (2005) Inhibition of cytokinezinduced $\mathrm{I} \kappa \mathrm{B}$ kinase activation as a mechanism contributing to the anti-atherogenic activity of tilianin in hyperlipidemic mice. Atherosclerosis 180:27-30

Oh SR, Jung KY, Lee HK (1996) In vitro anticomplementary activity of phenylpropanoids from Agastache rugosa. Korean J Pharmacogn 27(1):20-25

Oh HM, Kang YJ, Kim SH et al (2005) Agastache rugosa leaf extract inhibits the iNOS expression in ROS 17/2.8 cells activated with TNF-á and IL-1 $\beta$. Arch Pharm Res 28 (3):305-310

Oh HM, Kang YJ, Lee YS et al (2006) Protein kinase Gdependent heme oxygenase-1 induction by Agastache rugosa leaf extract protects RAW264.7 cells from hydrogen peroxide induced injury. J Ethnopharmacol 103:229-235

Omidbaigi R, Mahmoodi M (2010) Effect of irrigation regimes on the essential oil content and composition of Agastache foeniculum. J Essent Oil Bear Pl 13(1):59-65 
Omidbaigi R, Sefidkon F (2003) Essential oil composition of Agastache foeniculum cultivated in Iran. J Essent Oil Res 15(1):52-53

Omidbaigi R, Sefidkon F (2004) Effect of sowing time on the essential oil content and composition of Agastache foeniculum. J Essent Oil Bear Pl 7(2):190-194

Omidbaigi R, Kabudani M, Khoorang M (2008) Nitrogen fertilizer affecting herb yield, essential oil content and composition of Agastache foeniculum Purch. J Essent Oil Bear Pl 11(3):261-266

Ownagh A, Hasani A, Mardani K et al (2010) Antifungal effects of Thyme, Agastache and Satureja essential oils on Aspergillus fumigates, Aspergillus flavus, and Fusarium solani. Vet Res Forum 1(2):99-105

Park SU, Uddin MD, Xu H et al (2008) Biotechnological applications for rosmarinic acid production in plant. Afr $\mathrm{J}$ Biotechnol 7(25):4959-4965

Polak EH, Hixon RM (1945) The volatile oil from Lophantus anisatus Benth. J Am Pharm Assoc 35:240-243

Rudik GO (2013) Онтоморфогенез Agastache rugosa (Fisch. et C.A. Mey.) O. Kuntze ex situ. (Ontomorphogeny of Agastache rugosa (Fisch. et C.A. Mey.) O. Kuntze ex situ). Mod Phytomorphol 4:257-260

Sanders RW (1987) Taxonomy of Agastache section Brittonastrum (Lamiaceae-Nepeteae). Systematic Botany Monograph No 15. American Society of Plant Taxonomists. USA

Sandoval IV, Carrasco L (1997) Poliovirus infection and expression of the poliovirus protein $2 \mathrm{~B}$ provoke the disassembly of the Golgi complex, the organelle target for the antipoliovirus drug Ro-090179. J Virol 71:4679-4693

Shin S (2004) Essential oil compounds from Agastache rugosa as antifungal agent against Trichophyton species. Arch Pharm Res 27:295-299

Shin S, Kang CA (2003) Antifungal activity of the essential oil of Agastache rugosa Kuntze and its synergism with ketoconazole. Lett Appl Microbiol 36:111-115

Shin S, Pyun MS (2004) Anti-Candida effects of etragole in combination with ketoconazole or amphotericin B. Phytother Res 18:827-830

Shin S, Kim YS, Kang CA (2001) Production of volatile oil components by cell culture of Agastache rugosa $\mathrm{O}$. Kuntze. Nat Prod Sci 7:120-123

Skakovskii ED, Kiselev WP, Tychinskaya LY et al (2010) Characterisation of the essential oil of Agastache rugosa by NMR spectroscopy. J Appl Spectrosc 77(3):329-334

Song JH, Kim MJ, Kwon HD et al (2001) Antimicrobial activity and components of extracts from Agastache rugosa during growth period. J Food Sci Nutr 6:10-15

Suchorska-Tropiło K, Pióro-Jabrucka E (2004) Morphological, developmental and chemical analysis of the chosen $A$ gastache species. Ann Warsaw Univ Life Sci SGGW Horticult Landsc Architect 25:25-31

Suvitayavat W, Kodchawongs J, Thirawarapan SS et al (2004) Effects of Ya-hom on the gastric secretion in rats. J Ethnopharmacol 94:331-338

Svoboda KP, Gough J, Hampson J (1995) Analysis of the essential oils of some Agastache species grown in Scotland from various seed sources. Flavour Fragr J 10:139145

Tian GH, Liu CF, Lai PH et al (2009) Study on the essential oil obtained from the calyx of wild Agastache rugosa. Science and Technology of Food Industry. http://en.cnki.com.cn/ Article_en/CJFDTOTAL-SPKJ200910044.htm (cited 31 Dec 2013)

Tirillini BB, Menghlni AA, Pellegrino RR (1997) Constituents of the leaf secretory hairs of Agastache foeniculum $\mathrm{Ku}-$ ntze. J Essent Oil Res 9(1):19-21

Tuan PA, Park WT, Xu H et al (2012) Accumulation of tilianin and rosmarinic acid and expression of phenylpropanoid biosynthetic genes in Agastache rugosa. J Agric Food Chem 60:5945-5951

Vera-Montenegro Y, Ibarra-Velarde F, Ramirez-Avila Get al (2008) In vitro fasciolicide activity of some plant extracts against newly excysted flukes. Ann NY Acad Sci 1149:180-182

Verano J, Gonzales-Trujano ME, Deciga-Campos $\mathrm{M}$ et al (2013) Ursolic acid from Agastache mexicana aerial parts produces antinociceptive activity involving TRPV1 receptors, cGMP and a serotonergic synergism. Pharmacol Biochem 110:255-264

Vogelmann JE (1985) Crossing relationships among North American and Eastern Asian populations of Agastache sect. Agastache (Labiatae). Syst Bot 10(4):445-452

Vogelmann JE, Gastony GJ (1987) Electrophoretic enzyme analysis of North American and eastern Asian populations of Agastache sect. Agastache (Labiateae). Am J Bot 74:385-393

Wang JG (2010) GC-MS Analysis of chemical composition of volatile oil from Agastache rugosa. Food Sci 2010-08. http://en.cnki.com.cn/Article_en/CJFDTO-

TALSPKX201008052.htm. Cited 31 Dec 2013

Wang KH, Lin RD, Hsu FL et al (2006) Cosmetic applications of selected traditional Chinese herbal medicines. J Ethnopharmacol 106:353-359

Wang KC, Changb JS, Chiangd LC et al (2009) 4-Methoxycinnamaldehyde inhibited human respiratory syncytial virus in a human larynx carcinoma cell line. Phytomedicine 16:882-886

Weyerstahl P, Marschall H, Manteuffel E et al (1992) Volatile constituents of Agastache rugosa. J Essent Oil Res 4(6):585587

Wilson LA, Senechal NP, Widrlechner MP (1992) Headspace analysis of the volatile oils of Agastache. J Agric Food Chem 40(8):1362-1366

Wu C, Jiang X, He S et al (2010) Effects of QWBZP on T-cell subsets and their cytokines in intestinal mucosa of HRV infection suckling mice. J Ethnopharmacol 131:130-134

Wu Y, Li C, Li X et al (2013) Comparison of the essential oil compositions between Pogostemon cablin and Agatache rugosa used as herbs. J Essent Oil Bear Pl 16:705-713

$\mathrm{Xu}$ H, Kim YK, Jin X et al (2008) Rosmarinic acid biosynthesis in callus and cell cultures of Agastache rugosa Kuntze. J Med Plants Res 2(9):237-241

Zakharov AM, Dolya VS, Zakharova OI et al (1988) Essential and fatty oil of Agastache rugosa. Chem Nat Comp 24:448-450

Zakharova OI, Zakharov AM, Glyzin VI (1980) Flavonoids of Agastache rugosa. Chem Nat Comp 15:561-564

Zielińska S, Piatczak E, Kalemba D et al (2011) Influence of plant growth regulators on volatiles produced by in vitro grown shoots of Agastache rugosa (Fisher \& C.A.Meyer) O.Kuntze. Plant Cell Tissue Organ Cult 107:161-167

Zou ZM, Cong PZ (1991) Studies on the chemical constituents from roots of Agastache rugosa. Acta Pharmacol Sin 26 (12):906-910 